\title{
Comparative flood damage model assessment: towards a European approach
}

\author{
B. Jongman ${ }^{1,2}$, H. Kreibich ${ }^{3}$, H. Apel ${ }^{3}$, J. I. Barredo ${ }^{5}$, P. D. Bates ${ }^{4}$, L. Feyen ${ }^{5}$, A. Gericke ${ }^{3}$, J. Neal ${ }^{4}$, \\ J. C. J. H. Aerts ${ }^{1,2}$, and P. J. Ward ${ }^{1,2}$ \\ ${ }^{1}$ Institute for Environmental Studies (IVM), VU University Amsterdam, The Netherlands \\ ${ }^{2}$ Amsterdam Global Change Institute (AGCI), VU University Amsterdam, The Netherlands \\ ${ }^{3}$ Section Hydrology, German Research Centre for Geosciences (GFZ), Potsdam, Germany \\ ${ }^{4}$ School of Geographical Sciences, Bristol University, UK \\ ${ }^{5}$ European Commission - Joint Research Centre, Ispra, Italy
}

Correspondence to: B. Jongman (brenden.jongman@ivm.vu.nl)

Received: 26 June 2012 - Revised: 15 October 2012 - Accepted: 25 October 2012 - Published: 19 December 2012

\begin{abstract}
There is a wide variety of flood damage models in use internationally, differing substantially in their approaches and economic estimates. Since these models are being used more and more as a basis for investment and planning decisions on an increasingly large scale, there is a need to reduce the uncertainties involved and develop a harmonised European approach, in particular with respect to the EU Flood Risks Directive. In this paper we present a qualitative and quantitative assessment of seven flood damage models, using two case studies of past flood events in Germany and the United Kingdom. The qualitative analysis shows that modelling approaches vary strongly, and that current methodologies for estimating infrastructural damage are not as well developed as methodologies for the estimation of damage to buildings. The quantitative results show that the model outcomes are very sensitive to uncertainty in both vulnerability (i.e. depth-damage functions) and exposure (i.e. asset values), whereby the first has a larger effect than the latter. We conclude that care needs to be taken when using aggregated land use data for flood risk assessment, and that it is essential to adjust asset values to the regional economic situation and property characteristics. We call for the development of a flexible but consistent European framework that applies best practice from existing models while providing room for including necessary regional adjustments.
\end{abstract}

\section{Introduction}

Flooding of river systems is the most frequent and costly natural hazard, affecting the majority of the world's countries on a regular basis (UNISDR, 2011; IPCC, 2012). Over the past few decades the economic damage as a result of flooding has increased in most regions. Several studies state that most of this increase can be attributed to a growth of population and wealth in flood prone areas (Barredo, 2009; Bouwer et al., 2010; Kreft, 2011; UNISDR, 2011; Barredo et al., 2012). Studies of past flood events show that the majority of losses arise in urban areas, due to impairment of structures, costs of business shut-down and failure of infrastructure (EA, 2010; ADB and The World Bank, 2010). Government agencies, insurance companies and research institutions in many countries develop and use flood damage models to assess the expected economic flood impact. Estimates of potential exante damage are used, for example, for land use planning, flood risk mapping and cost-benefit analysis of required investments in flood defences (e.g. Charnwood Borough Council, 2003; Kind, 2011).

Flood damage can be divided into four types: direct tangible (e.g. physical damage due to contact with water), indirect tangible (e.g. loss of production and income), direct intangible (e.g. loss of life) and indirect intangible (e.g. trauma) (e.g. Smith and Ward, 1998; Messner et al., 2007; Merz et al., 2010; Bubeck and Kreibich, 2011). In this paper we will only assess methodologies relating to the estimation of direct tangible damage. The estimation of direct flood damage 
is a complex process involving a large number of hydrologic and socioeconomic factors. The structure, inputs and outputs of a specific damage model are defined not only by the available data, but also by the purpose of the model. For example, while insurance companies model the estimated insured damages, government agencies and academics are generally interested in the accurate assessment of total economic losses. All damage models are by definition based on a degree of generalisation, but the level of detail varies significantly between them.In this paper we compare a range of flood damage models in order to qualify and quantify the differences.

In almost all models in use today, flood depth is treated as the determining factor for expected damage, sometimes complemented by other parameters like velocity, duration, water contamination, precaution and warning time (Messner et al., 2007; Merz et al., 2010; Green et al., 2011). Some recently developed multi-parameter models are conceptual (Nicholas et al., 2001) or developed (and validated) for specific areas, e.g. for Japan (Zhai et al., 2005) or FLEMO for Germany (Kreibich et al., 2010). Thus, more research is needed on their validation and transferability (e.g. in this study the German multi-parameter model FLEMO is included).

However, the internationally accepted and most common method for the estimation of direct flood damage is still the application of depth-damage functions (Smith, 1994; Kelman and Spence, 2004; Meyer and Messner, 2005; Merz et al., 2010; Green et al., 2011). Depth-damage functions represent relationships between flood depth and the resulting monetary damage. For a given flood depth the function gives expected losses to a specific property or land use type, either as a percentage of a pre-defined asset value (relative function) or directly in financial terms (absolute function).

There is a large degree of uncertainty in the construction of the damage curves, the asset values connected to these curves and the larger methodological framework (Merz et al., 2004; Hall et al., 2005; Meyer and Messner, 2005; Messner et al., 2007; Apel et al., 2008; Freni et al., 2010; Merz et al., 2010; De Moel and Aerts, 2011; Green et al., 2011; Ward et al., 2011). Differences in the methodological framework of flood damage models are for example apparent in the spatial scale (object- versus area-based), damage-function type (absolute versus relative), damage classes, cost base (replacement cost versus depreciated cost) and the number of hydrological characteristics included. Also, while some damage models are constructed using empirical damage data, others are defined on expert judgement in combination with artificial inundation scenarios.

De Moel and Aerts (2011) show that uncertainty in depthdamage curves and corresponding asset values constitutes the most important factor in damage estimation, and has a much stronger effect on the outcome than uncertainties in hydrological and land use ("assets at stake") inputs. The assessment and reduction of these uncertainties by crosscomparison of damage models is important on two levels.
First, it can be used to improve currently existing flood damage models and their results. Second, it can assist in the development of a consistent supra-national damage assessment approach (te Linde et al., 2010; Bubeck et al., 2011). In the EU Flood Risks Directive, consistency in assessment methods is already aimed at within individual river basins in the European Union (European Parliament, 2007). On a larger scale, there is an increasing interest in a harmonised Europewide modelling approach (Lugeri et al., 2006; De Roo et al., 2007; Barredo and De Roo, 2010). Such a consistent modelling approach could be valuable for the identification of areas of high potential risk; the support of European policy; and the estimation of the expected costs of compensation mechanisms such as the EU Solidarity Fund (European Council, 2002; Hochrainer et al., 2009). A first pan-European damage model has been developed on the request of the European Commission - Joint Research Centre (Huizinga, 2007), and is discussed in Sect. 4.

Flood damage modelling methodologies have been evaluated in several comparison studies (e.g. Meyer and Messner, 2005; Messner et al., 2007; Merz et al., 2010; De Moel and Aerts, 2011; Green et al., 2011). However, these studies either: (1) focus on a small selection of models; (2) are limited to qualitative assessment; or (3) only measure quantitative model outcomes relative to other models due to a lack of available empirical damage data. In this paper we present a first comprehensive qualitative and quantitative comparison of seven damage models. The objectives are to identify strengths and weaknesses in existing modelling approaches, specify the uncertainties involved and use these findings to assist the development of a harmonised European approach. We conducted the qualitative comparison by analysing the properties of the models using a literature study, and comparing them on a set of defined aspects. We carried out the quantitative assessment by running all models on two case studies of past flood events, for which both spatial hydrological and land use data as well as reported flood damage data are available.

\section{Case studies}

The first case study for the quantitative comparison of damage model outcomes is based on a 2002 flood event in Eilenburg, Germany (Fig. 1). The second case study covers the 2005 flooding in Carlisle, United Kingdom (Fig. 2). Both flood events have been analysed in detail in several previous studies outlined below, and the available data are used in subsequent sections of this paper to estimate uncertainties involved in flood damage modelling.

\section{$2.1 \quad$ Eilenburg}

The August 2002 flooding of the Mulde River in the German municipality of Eilenburg, Saxony (Fig. 1), has been 

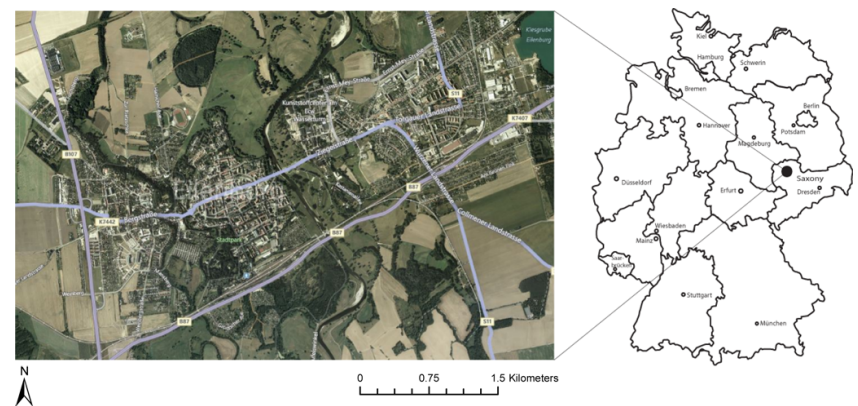

Fig. 1. Location and map of the case study area of Eilenburg in the province of Saxony, Germany.

documented extensively and used as a case study in several preceding flood risk studies (e.g. Apel et al., 2009; Kreibich et al., 2009; Kuhlicke, 2008; Meyer et al., 2009). During the flood event, water reached a depth of up to $5 \mathrm{~m}$ in large parts of the city, forcing the evacuation of ca. 10000 people. An estimated area of 9.2 million $\mathrm{km}^{2}$ was inundated, consisting of approximately 3.4 million $\mathrm{km}^{2}$ of built-up area and infrastructure, and 5.8 million $\mathrm{km}^{2}$ of agriculture and natural land cover, resulting in total damage estimated at $€ 218$ million (Sect. 2.2.3).

The federal state of Saxony has a population of over 4 million people, with a GDP per capita of approximately $€ 21000$, compared to $€ 29000$ for Germany as a whole (European Commission, 2012). Compared to the German average, a relatively large part of the Saxon economy is based on industry, construction and public services (SMWA, 2010). Financial services and trade contribute less to the economy in relative terms compared to the national average. Eilenburg is located in the north-western district of Saxony, about $20 \mathrm{~km}$ from the city of Leipzig, and has a population of 19000 . The Eilenburg region has a history of flooding, with high water events in the 20th century in 1926, 1932, 1954, 1958, 1974 and 2002 (Pech et al., 2008).

\subsection{Carlisle}

Between 7 and 9 January 2005, 36h of heavy rain caused a discharge with an estimated return period of $150 \mathrm{yr}$ in the river Eden in the county of Cumbria (Day, 2005), leading to severe flooding along the length of the river. In the county capital, Carlisle (Fig. 2), 1844 properties were affected and three people lost their lives. The inundated area covered an estimated 2.3 million $\mathrm{km}^{2}$, of which 1 million $\mathrm{km}^{2}$ consisted of built-up area and infrastructure, and the rest of nature and agriculture. Total losses are estimated at $£ 383$ million (€535 million $^{1}$ ) (Sect. 2.2.3).

Cumbria has a total population of 496000 , of which 77000 live in Carlisle. The GDP per capita of Cumbria was approximately $£ 23000$ ( $€ 32000$ ), compared to an average

\footnotetext{
${ }^{1}$ At exchange rate of January 2005.
}
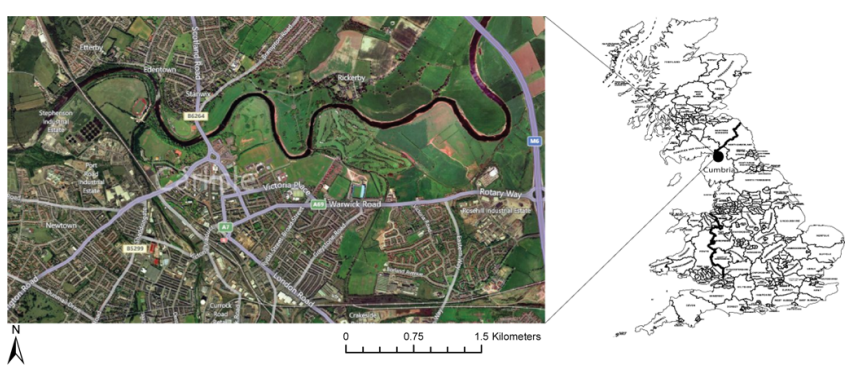

Fig. 2. Location and map of the case study area of Carlisle in the county of Cumbria, United Kingdom.

of $£ 30000$ ( $€ 42000$ ) in England (Office for National Statistics, 2012). The relative sectoral employment in Carlisle is generally in line with the national average, except for larger proportions working in agriculture $(3.1 \%$ versus $1.5 \%)$ and manufacturing ( $15.9 \%$ versus $14.8 \%$ ), and a smaller fraction employed in finance and property $(10.4 \%$ versus $18.0 \%)$ (Office for National Statistics, 2005). Similar to the Mulde river in Germany, the Eden river basin has a history of flood events recorded as far back as the 1700s. Floods in recent years have been recorded in 1963, 1968, 1979, 1980, 1984 and 2005.

\section{Methodologies}

We qualitatively and quantitatively compared seven flood damage models developed for simulating direct flood damage: FLEMO (Germany), Damage Scanner (The Netherlands), Rhine Atlas (Rhine basin), the Flemish Model (Belgium), Multi-Coloured Manual (United Kingdom), HAZUSMH (United States) and the JRC Model (European Commission/HKV). We are aware that more damage models are available, but we selected these specific ones because: (1) for these models there is enough background information available for consistent comparison; (2) they all use water depth as the main determining parameter for direct damage estimation; and (3) they were developed in economically similar regions as the case studies. Furthermore, all models involved in this study are developed and applied by governments and academic institutions rather than the insurance industry, which ensures a degree of consistency in the purpose of the models. We compared the models quantitatively on the basis of two case studies described in Sect. 2.

\subsection{Qualitative assessment}

The framework used for the qualitative assessment of the damage models is presented in Fig. 3. We assessed all models on three main aspects: scale, input data and damage calculation. On the basis of preceding comparison studies (e.g. Meyer and Messner, 2005; Messner et al., 2007; Merz et al., 
2010), we defined nine specific characteristics within these three categories that were compared between models:

- Scale of application: the spatial scale of application for which the model is developed, ranging from local to supra-national;

- Regional differentiation: the options for differentiation in parameters (such as maximum damage values) between areas of analysis;

- Units of analysis: the units used for damage estimation, which can be the level of individual objects or aggregated land use classes, or a combination of these;

- Hydrological characteristics: the inundation characteristics taken into account in damage assessment, such as depth, duration, velocity and contamination;

- Data method: the method used in developing the damage models, either using empirical data from past flood events or synthetic data from "what-if" analyses of a simulated potential flood;

- Land use classification: the detail of the classification system used to differentiate between various object or land use types;

- Cost base: the type of values on which the maximum damage per object or land use class is based. The values can be expressed as either replacement costs, i.e. the estimated new value of the object or class, or depreciated/repair costs, i.e. an estimate of the present-day cost of replacement or reparation. Replacement costs represent total expected monetary flows and are an estimated factor 2 higher than depreciated costs, which express real economic loss (e.g. ICPR, 1998; Penning-Rowsell et al., 2010);

- Empirical validation: the validation of the damage model after development on the basis of reported flood damage data;

- Damage functions: the type of depth-damage function, which can represent either the relative percentage loss with respect to a pre-defined maximum damage value, or the absolute monetary loss with depth.

The model description in Sect. 3 also includes information on complementary aspects such as the methodologies with respect to indirect effects, but these will not be discussed further in the results section.

\subsection{Quantitative assessment}

We carried out a quantitative comparison and sensitivity analysis of the various damage models using the flood events in Carlise and Eilenburg described in Sect. 2. In the following subsections, we describe the steps required in this process.

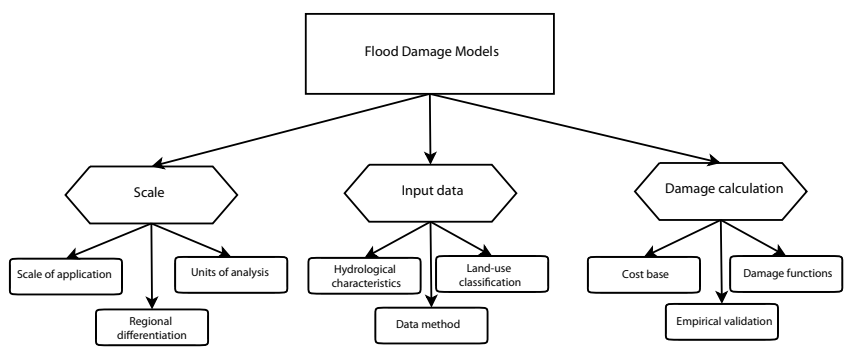

Fig. 3. Schematic display of the framework for qualitative assessment of the damage models included in this study. The summarised results are listed in Table 3.

\subsubsection{Damage modelling}

In order to calculate flood damages with the different damage models, several inputs are needed for both case study areas. First, we obtained inundation maps, which provide flood depths for the inundation zones in Eilenburg and Carlisle (Sect. "Inundation maps"). Second, we constructed consistent land use maps for both areas using freely available European datasets (Sect. "Land use maps"). Finally, we adjusted the damage models to enable their application with these land use maps (Sect. "Damage model modification").

\section{Inundation maps}

Both case study areas have recently been subject to a significant flood event, inundating an estimated 1 to 3 million $\mathrm{km}^{2}$ in Carlisle and Eilenburg respectively, and affecting thousands of properties. After the events, discharge patterns were reconstructed using measuring gauges, on the basis of which various inundation models with different complexity were built to simulate water depths and flow velocities (Fig. 4). The depth histograms for both study areas are presented in Fig. 5.

\section{Eilenburg}

Because of the large impact of the event, the hydrological characteristics of the Eilenburg flooding have been studied in detail. River discharges were measured at the nearby gauging station of Golzern. In addition, maximum inundation depths were recorded at 380 observation points throughout the city (J. Schwarz et al., personal communication, 2005). On the basis of the discharge, and a $25 \mathrm{~m} \times 25 \mathrm{~m}$ DEM, Apel et al. (2009) simulated the flooded area using four different inundation models, which were calibrated using the node data of observed flood depths. In the present study we use inundation depths from the 1-D/2-D model, which was found by Apel et al. (2009) to be the most suited approach (Fig. 4). 

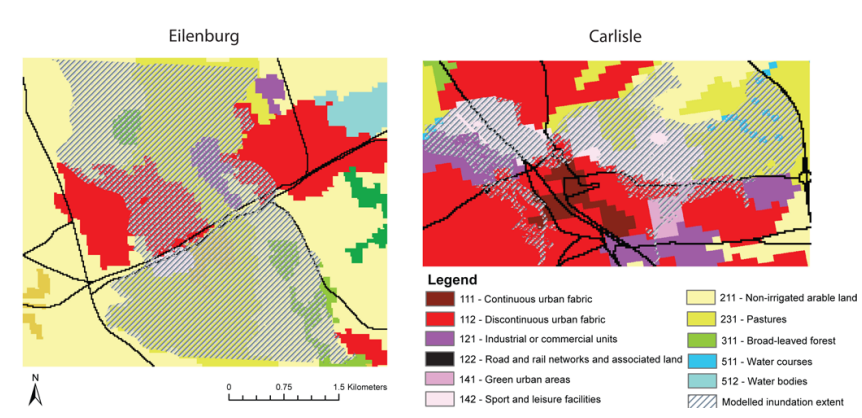

Fig. 4. The case study areas of Eilenburg and Carlisle with the land use and inundation data used in this study. The land use data consist of CORINE 2006 (EEA, 2009) and manually added main roads from ESRI Europe Base Map (ESRI, 2009). The inundation areas are derived from various modelling efforts that are further explained in Sect. 2.2.1.

\section{Carlisle}

As is the case in Eilenburg, the flood that occurred in Carlisle in 2005 has subsequently been the focus of several inundation simulations (e.g. Neal et al., 2009, 2012; Horrit et al., 2010; Fewtrell et al., 2011). In the present study, we use the results of a 2-D inertial wave model (Bates et al., 2010) developed using the 2-D channel geometry from Horritt et al. (2010). The model is based on a deterministic approach, using gauged hydrographs, LiDAR elevation data, and Mastermap®land use data to aid the LiDAR processing (Mason et al., 2007). Discharge data were available from four Environment Agency gauging stations along the river. In addition, an ex-post survey delivered a set of 263 water marks that were used for roughness calibration (Neal et al., 2009). The resulting inundation map covers the larger Carlisle city area with a horizontal resolution of $5 \mathrm{~m} \times 5 \mathrm{~m}$ and has a vertical root mean square error of $0.26 \mathrm{~m}$ with the checked water marks. Compared to the Eilenburg simulation, the Carlisle inundation area is smaller (Fig. 4) and has relatively fewer cells with high $(>2 \mathrm{~m})$ flood depths (Fig. 5).

\section{Land use maps}

To ensure a consistent comparison between the two case study areas, we use CORINE 2006 (EEA, 2009) land cover data, which is available in both areas. The resolution of the land use data is $100 \mathrm{~m} \times 100 \mathrm{~m}$. From the original CORINE data, we selected the classes " 111 - Continuous urban fabric", "112 - Discontinuous urban fabric", "121 - Industrial or commercial units" and "122 - Road and rail networks and associated land", which are the areas containing residential, commercial, industrial and infrastructural constructions. Since we observed that CORINE does not classify any surface within the two case study areas as infrastructure and associated land, we added the main roads manually to this class using ESRI's Europe Base Map (ESRI, 2009) (Fig. 4).

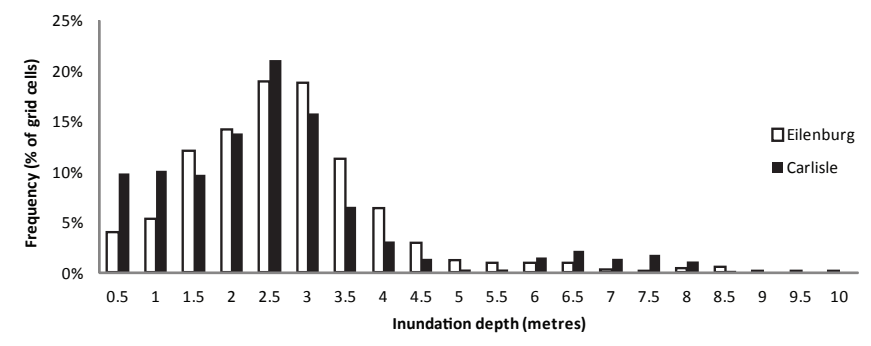

Fig. 5. Histogram of the validated inundation depth simulations for the Eilenburg and Carlisle case studies. The histogram provides the percentage of grid cells (y-axis) inundated with a water depth within a specific $50 \mathrm{~cm}$ interval ( $\mathrm{x}$-axis).

\section{Damage model modification}

We conducted a comparative damage assessment by applying the various damage models to the study areas employing the simulated flood inundation depths and CORINE 2006 land cover data (Fig. 4). In order to compute direct damage for the two available case studies in a consistent way, we adjusted the seven models to be compatible with CORINE land cover data. For most damage models the adjustment to CORINE led to two main generalisations. First, the spatial resolution of the land use input was set to the CORINE $100 \mathrm{~m} \times 100 \mathrm{~m}$ grid size. Second, the number of classes was decreased to match the four selected CORINE classes containing urban, commercial/industrial and infrastructural land cover.

For all models one original depth-damage curve and corresponding maximum damage value was assigned to each CORINE land use class (Table 1). If more than one original model class could be applicable to a certain CORINE class, we chose the class that was considered to be most comparable to the other models. For example, from the HAZUS residential classification we selected the class three or more floors, no basement, since this corresponds best to building types assumed in the Damage Scanner, Multi-Coloured Manual and Rhine Atlas models. Five out of seven damage models used in this study (FLEMO, Damage Scanner, Rhine Atlas, Flemish Model, JRC Model) are developed for aggregated land use data such as CORINE, which take into account that each of the land use classes containing built-up area also include a fair share of less damage-prone land cover apart from buildings (e.g. gardens and public grounds in residential areas). In contrast, HAZUS and the Multi-Coloured Manual are specifically designed for individual objects and thus cannot be applied directly to CORINE land use data. Therefore, we analysed the average surface and density of buildings in each of the case study areas and adjusted the maximum damage values accordingly (Table 2). For Eilenburg, the building surface and density estimates were derived from a detailed dataset covering all individual buildings in the city (Apel et al., 2009). For Carlisle, we used $1 \mathrm{~m} \times 1 \mathrm{~m}$ resolution MasterMap ${ }^{\circledR}$ land use data in combination with 
Table 1. Reclassification of the original categories of the damage models to the four CORINE land use classes applied in this study. Selection of a specific damage category is done manually, whereby the median category is chosen in case of multiple possibilities.

\begin{tabular}{|c|c|c|c|c|c|c|c|c|}
\hline \multicolumn{2}{|c|}{ CORINE classification } & \multicolumn{7}{|c|}{ Original classification } \\
\hline $\begin{array}{l}\text { CLC } \\
\text { Code }\end{array}$ & CLC Label & FLEMO & $\begin{array}{l}\text { Damage } \\
\text { Scanner }\end{array}$ & $\begin{array}{l}\text { Flemish } \\
\text { method }\end{array}$ & HAZUS-MH & $\begin{array}{l}\text { Multi-Coloured } \\
\text { Manual }\end{array}$ & Rhine Atlas & JRC Approach \\
\hline 111 & $\begin{array}{l}\text { Continuous } \\
\text { urban fabric }\end{array}$ & $\begin{array}{l}\text { Mixed } \\
\text { residential plus } \\
\text { average } \\
\text { commercial }\end{array}$ & $\begin{array}{l}\text { High density } \\
\text { urban areas }\end{array}$ & Residential & $\begin{array}{l}\text { Residential, } \\
\text { three or more } \\
\text { floors, no } \\
\text { basement }\end{array}$ & $\begin{array}{l}\text { Residential } \\
\text { homes average } \\
\text { (indicative } \\
\text { susceptibility) }\end{array}$ & Residential & Linked to CLC \\
\hline 112 & $\begin{array}{l}\text { Discontinuous } \\
\text { urban fabric }\end{array}$ & $\begin{array}{l}\text { Mixed } \\
\text { residential plus } \\
\text { average } \\
\text { commercial }\end{array}$ & $\begin{array}{l}\text { Mixed } \\
\text { urban-green } \\
\text { areas }\end{array}$ & Residential & $\begin{array}{l}\text { Residential, } \\
\text { three or more } \\
\text { floors, no } \\
\text { basement }\end{array}$ & $\begin{array}{l}\text { Residential } \\
\text { homes average, } \\
\text { (indicative } \\
\text { susceptibility) }\end{array}$ & Residential & Linked to CLC \\
\hline 121 & $\begin{array}{l}\text { Industrial or } \\
\text { commercial } \\
\text { units }\end{array}$ & $\begin{array}{l}\text { Average } \\
\text { commercial } \\
\text { and industrial }\end{array}$ & $\begin{array}{l}\text { "Labour" } \\
\text { (commercial } \\
\text { plus industrial) }\end{array}$ & Industrial & $\begin{array}{l}\text { Average light } \\
\text { industrial }\end{array}$ & $\begin{array}{l}\text { Weighted mean } \\
\text { retail } \\
\text { (indicative } \\
\text { susceptibility) }\end{array}$ & $\begin{array}{l}\text { Industrial (incl. } \\
\text { commercial) }\end{array}$ & Linked to CLC \\
\hline 122 & $\begin{array}{l}\text { Road and rail } \\
\text { networks and } \\
\text { associated land }\end{array}$ & - & Infrastructure & Roads and rail & - & $\begin{array}{l}\text { Estimated } \\
\text { percent }\end{array}$ & $\begin{array}{l}\text { Traffic, } \\
\text { immobile }\end{array}$ & Linked to CLC \\
\hline
\end{tabular}

information on the total count of buildings. The new maximum damage values represent the expected damage to buildings within the respective CORINE land use classes.

The depth-damage functions (Fig. 6) give the percentage loss (y-axis) to the maximum damage values as a function of water depth (x-axis). As has been shown in previous studies (e.g. Barredo and De Roo, 2010), the models vary strongly in terms of the shape of the applied functions and maximum damage values.

\subsubsection{Empirical comparison}

In this study we aim at comparing the damage models mutually as well as with reported damage figures provided by financial institutions. To facilitate this comparison, we analysed the empirical damage data available, and as far as possible linked the data to the four CORINE land use classes used to run the damage models.

\section{Eilenburg}

The direct economic damage of the 2002 flood in Eilenburg was documented by Saxonian Relief Bank (SAB). According to $\mathrm{SAB}$ data, an estimated 765 residential properties were affected with a total damage of $€ 77.1$ million. Damage to commercial buildings totalled an estimated $€ 33.9$ million (Apel et al., 2009; Seifert et al., 2010a; SAB, personal communication, 2004). Infrastructure losses were not reported by SAB. However, the federal state of Saxony has published a report for the whole of Saxony, reporting damage to infrastructure of 1.4 times residential losses (Leitstelle Wiederaufbau, 2003). Infrastructure losses in Eilenburg resulted from a collapse of a railway bridge and severe damage to roads, amongst other things. Thus, assuming the Saxony-wide 1.4 ratio of infrastructure to residential losses is approximately

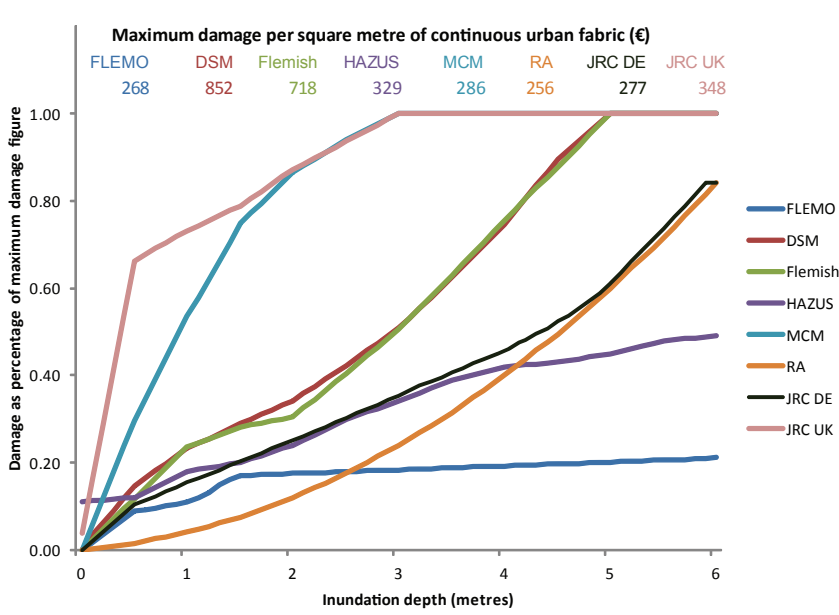

Fig. 6. Depth-damage functions and corresponding maximum damage figures for the CORINE land use class "continuous urban fabric". The functions of each damage model are based on a manual selection of available damage classes, except for the JRC Model which is designed to match CORINE land use data (Table 1; Sect. 3).

the same in Eilenburg, we estimated infrastructure losses for the case study area at $€ 109$ million. Hence, total damage is estimated at $€ 218$ million.

\section{Carlisle}

The Association of British Insurers estimated the total insured damage in Carlisle at $£ 272$ million ( $€ 382$ million $^{2}$ ). Although a more detailed breakdown of damage from this event is not available, we have made an estimate on the basis

\footnotetext{
${ }^{2}$ At exchange rate of January 2005.
} 
Table 2. Conversion of original object-based maximum damage values of HAZUS and MCM (left) to area-based values (right), on the basis of average building densities and surface areas for Eilenburg and Carlisle. Building densities and surface area estimates are derived from a spatial dataset of individual buildings for Eilenburg and $1 \mathrm{~m} \times 1 \mathrm{~m}$ resolution MasterMap®data for Carlisle, specifically for the areas in the simulated inundation zones (Fig. 4).

\begin{tabular}{|c|c|c|c|c|c|c|c|c|c|c|}
\hline \multirow{3}{*}{ CLC Code } & \multicolumn{2}{|c|}{$\begin{array}{c}\text { Object-based } \\
\text { maximum damage } \\
\left(€ \mathrm{~m}^{-2}\right)\end{array}$} & \multicolumn{2}{|c|}{$\begin{array}{c}\text { Average } \\
\text { building surface } \\
\text { area }\left(\mathrm{m}^{2}\right)\end{array}$} & \multicolumn{2}{|c|}{$\begin{array}{c}\text { Average } \\
\text { building density } \\
\left(\# \mathrm{ha}^{-1}\right)\end{array}$} & \multicolumn{4}{|c|}{$\begin{array}{l}\text { Area-based } \\
\text { maximum damage } \\
\left(€ \mathrm{~m}^{-2}\right)\end{array}$} \\
\hline & \multirow{2}{*}{ HAZUS } & \multirow{2}{*}{ MCM } & \multirow{2}{*}{ Eilenburg } & \multirow{2}{*}{ Carlisle } & \multirow{2}{*}{ Eilenburg } & \multirow{2}{*}{ Carlisle } & \multicolumn{2}{|c|}{ HAZUS } & \multicolumn{2}{|c|}{ MCM } \\
\hline & & & & & & & Eilenburg & Carlisle & Eilenburg & Carlisle \\
\hline 111 & 823 & 714 & - & 100 & - & 40 & - & 329 & - & 286 \\
\hline 112 & 823 & 714 & 105 & 120 & 15 & 25 & 130 & 247 & 113 & 214 \\
\hline 121 & 1156 & 1290 & 114 & 135 & 10 & 15 & 132 & 234 & 147 & 261 \\
\hline
\end{tabular}

of the detailed economic assessment after the wide-spread flooding that occurred across England during the year 2007 (EA, 2010). The EA report outlines that: (1) $75 \%$ of household losses and $95 \%$ of commercial and industrial damage were insured; and (2) an average of $54 \%$ of the total damage was attributed to households, the other $32 \%$ to commercial and industrial properties and $14 \%$ to infrastructure. Applying the relative losses per class found in this study to the available insured damage data for Carlisle, we estimated total direct damage at $£ 228$ million ( $€ 321$ million), $£ 108$ million ( $€ 151$ million) and $£ 46$ million ( $€ 64$ million) to residential properties, commercial/industrial units and infrastructure, respectively. Total direct damages amount to $£ 383$ million ( $€ 535$ million). Note that the estimated damage to infrastructure in Carlisle is much lower relative to the total damage than the figures estimated for Eilenburg. This is mainly a result of high losses from a railway bridge and road sections in the Eilenburg area.

\subsubsection{Sensitivity analysis}

Finally, we conducted a sensitivity analysis to quantify the effect of uncertainties associated with the modelling of flood damage. In the analysis we distinguished between two different types of uncertainties: function uncertainty and value uncertainty. The first is defined as sensitivity of the outcome to uncertainty in the shape of the depth-damage functions, while the latter relates to uncertainty in maximum damage values. We calculated function uncertainty by combining fixed maximum damage estimates with all seven depthdamage functions. Following the same logic, we computed value uncertainty by combining a fixed depth-damage function with all seven maximum damage values and assessed the spread. Both types of uncertainty can be expressed in terms of the absolute and relative difference between the highest and lowest damage estimates. We refer to these as absolute valuelfunction uncertainty and relative valuelfunction uncertainty, respectively.

\section{Flood damage models}

In this section we provide a brief description of the focus, development and characteristics of the different models included in this study, as well as an explanation on the application of each model in the quantitative section of our study. The aim of this section is to identify key methodological dissimilarities, rather than to provide an exhaustive description of the approaches. For more detailed information, the reader is referred to the publications cited.

\subsection{FLEMO}

The FLEMO model family has been developed at the German Research Centre for Geosciences, primarily for scientific flood risk analyses from the local to national scale (e.g. Apel et al., 2009; Vorogushyn et al., 2012). It contains the rule-based multi-factorial Flood Loss Estimation MOdel for the private sector (FLEMOps) for the estimation of direct tangible damage to residential buildings (Thieken et al., 2008) and the rule-based multi-factorial Flood Loss Estimation MOdel for the commercial sector (FLEMOcs) for the estimation of direct tangible damage to buildings, equipment and goods of companies (Kreibich et al., 2010; Seifert et al., 2010a).

FLEMOps calculates the flood damage using five different classes of inundation depth, three individual building types, two classes of building quality, three classes of contamination and three classes of private precaution (Thieken et al., 2008). The FLEMOps model has been further developed for different flood types (Kreibich and Thieken, 2008; Elmer et al., 2010, Kreibich et al., 2011a), but these specific versions have not been used in this study. FLEMOcs has a similar structure, it calculates the flood damage using five classes of inundation depth, four different economic sectors, three classes of company size in respect to the number of employees as well as three classes of contamination and three classes of private precaution (Kreibich et al., 2010).

The models are based on empirical damage data from the floods in 2002, 2005 and 2006 in the Elbe and Danube 
catchments in Germany (Thieken et al., 2007; Kreibich et al., 2007, 2011b). For local studies the models are applicable on the building level (micro-scale). For applications on the regional to national level (meso-scale) the models have been adapted using census, geo-marketing and land use data. For the Germany-wide application, asset values of residential buildings and companies have been calculated and disaggregated on different land use classes (Kleist et al., 2006; Thieken et al., 2006; Seifert et al., 2010b; Kreibich et al., 2010). The models have been intensively validated on the micro- as well as on the meso-scale using different data sets of repair costs at the scale of single buildings and whole municipalities (Thieken et al., 2008; Seifert et al., 2010a).

To enable an easy quantitative comparison with the other damage models in this study, simplified adapted model versions are used in this study: FLEMOps for estimating residential damage and FLEMOcs to estimate commercial and industrial damage. The models have been reduced to their main determining parameter, i.e. water-depth, in only using their depth-damage functions. For the model parameters residential building types and quality (FLEMOps) and economic sectors and company size (FLEMOcs), average values per case study area have been used. Only the first model stage of both models has been applied, which means that contamination and precaution have not been taken into consideration. Results of the application and validation of the full FLEMOps model in Eilenburg have been published by Apel et al. (2009).

\subsection{Damage Scanner}

The standard method for the detailed estimation of flood damage in the Netherlands is the Damage and Victims Module (SSM) (Kok et al., 2005). The HIS-SSM model is used extensively by government agencies to estimate potential flood damage on a regional or national scale and calculate economically efficient investments in defences (Kind, 2011). The disadvantage of the HIS-SSM is that it requires highly detailed data on individual buildings, industries and infrastructures. Since this information is not always available, the Damage Scanner model (DSM) was developed (Klijn et al., 2007). The Damage Scanner is based on the economic values and depth-damage curves of the HIS-SSM module, but works with aggregated land use data instead of individual units. It is specifically designed for estimations at the regional scale and local variations are averaged out as much as possible. Maximum damage values for identical land use classes are defined at the national scale and do not vary spatially. Also, velocity is not taken into account as an influencing factor. The Damage Scanner has been used for the estimation of future flood risk under climate and land use changes in various regions of the Netherlands (e.g. Bouwer et al., 2010; Aerts and Botzen, 2011; te Linde et al., 2011; De Moel et al., 2011; Ward et al., 2011; Poussin et al., 2012).

Nat. Hazards Earth Syst. Sci., 12, 3733-3752, 2012
The underlying estimates of the Damage Scanner are mainly based on synthetic data, using "what-if analyses" estimating the damage that would be expected in case of a certain flood situation. Maximum damage values are based on rebuilding values (buildings), replacement values (contents) and market values (agriculture) (Briene et al., 2002). Indirect losses are calculated as an additional $5 \%$ on top of the direct losses, and are consequently also subject to depth-damage curves.

The application of the Damage Scanner in our case study areas was relatively straight-forward, since the land use classification of the Damage Scanner already corresponds well to the CORINE system. Similar to CORINE, the Damage Scanner recognises a high density and a medium density class for urban areas, plus an additional low density class for rural areas which we did not use. Also, the Damage Scanner has a single land use class for "Labour", including both commercial and industrial properties, and one class for infrastructure. The asset and vulnerability estimates for the aggregated urban classes of the Damage Scanner assume a degree of nonproperty land-occupation such as roads and open space.

\subsection{Flemish model}

A model for flood damage estimation developed for the Flemish Environmental Agency in Belgium is described by Vanneuville et al. (2006). Similar to the Damage Scanner, the Flemish methodology is specifically designed for assessments on a regional and national scale using aggregated land use data. The methodology has been applied for identifying vulnerable areas (Vanderkrimpen et al., 2009) and calculating efficient flood defence investments (Giron et al., 2010).

The maximum damage values in the Flemish model are based on national averages of housing prices, surface areas and market values. Damage to residential content is assumed to be $50 \%$ of the structural losses. Furthermore, indirect costs are included as a percentage on top of the direct damage, ranging from $10 \%$ for agriculture to $40 \%$ for industry.

The Flemish model has been developed specifically for aggregated land use data and, like the Damage Scanner, tailoring to CORINE for the use in our quantitative analysis was relatively simple. The Flemish model has a separate structure and content class for residential areas, which we summed and allocated to the CORINE urban fabric classes. There is only one infrastructure and one "industry" (industry plus commerce) class

\subsection{HAZUS-MH}

The HAZUS Multi-Hazard software (FEMA, 2009; Scawthorn, 2006) is a tool for the estimation of the potential economic, financial and societal effects of natural hazards within the United States. HAZUS-MH comprises water, wind and earthquake induced hazards. In this paper we only discuss the Flood Model. The HAZUS-MH Flood Model 
has been applied in different settings, to spatially assess potential flood risk (e.g. FEMA Region IV, 2008) or plan actual emergency support for upcoming flood events (e.g. FEMA Region VII, 2008). The typical scales of application are city, county and state level.

The development of HAZUS started in 1997 with an exploratory study and continued to the publication of HAZUSMH MR4 in 2009. Over several years, all inputs required for flood damage estimation were collected and included in the software:

- building data on the census block level, including building type, number of floors, presence of a basement and date of construction;

- infrastructure and high-potential facilities (e.g. hospitals, energy plants) data on an object level, with information on construction costs for all infrastructural objects;

- a large number of nationally applicable depth-damage functions for buildings developed by the Federal Insurance Agency on the basis of $20 \mathrm{yr}$ of empirical damage data, as well as separate functions developed by the US Army Corps of Engineers (USACE) for specific regions of the United States;

- failure probabilities and damage functions for infrastructure, constructed on the basis of modelling, expert opinion and historical data;

- a separate module for the estimation of indirect costs and larger economic effects of the flood event, with functions based on user-defined economic variables (e.g. size of the economy and unemployment figures).

Users of the HAZUS software have to choose between a basic "level 1" analysis using default input data, a "level 2" analysis using default data supplemented with regionally specified information, or a "level 3" analysis that requires extensive additional economic and engineering studies by the user. This choice pertains to both direct and indirect cost estimations. Ding et al. (2008) have shown that level 2 analyses bring more reliable results than level 1 analyses. Furthermore the user can define the intensity and timing of the flood, how much warning time the community has, and whether the losses should be calculated on the basis of replacement or depreciated asset values.

The high level of detail of HAZUS implies that we have to make several decisions when applying the model to our case studies on the basis of aggregated land use data. First, out of the different HAZUS object classes we selected one function for each CORINE land use class, thereby picking the class that was considered most consistent with the other models (Table 1). We used maximum damage values based on replacement values, not depreciated values. Since HAZUS is an object-based model with maximum damage values only reflecting actual buildings and not the surrounding area, we adjusted the values by an estimated building surface area per CORINE grid cell (Table 2). The resulting area-weighted maximum damage estimates for the selected CORINE land use classes are $61-88 \%$ lower than the maximum damage estimates for individual objects, and should be more suited to reflect the reported damage patterns.

\subsection{Multi-Coloured Manual}

The Multi-Coloured Manual (MCM) and its predecessors present the most advanced method for flood damage estimation within Europe (e.g. Penning-Rowsell and Chatterton, 1977; Penning-Rowsell et al., 1992, 2010). The purpose of the MCM is explicitly defined as to support water management policy and enable quantitative assessment of the effect of investment decisions (Penning-Rowsell et al., 2010, p. 1). For these purposes, Penning-Rowsell et al. (2010) have developed a wide range of depth-damage relationships and additional methodologies for the estimation of the losses and benefits of flooding.

Contrary to most other damage models, the MCM assesses building losses using absolute depth-damage curves, defining potential damage in British Pounds with depth, rather than using relative curves and maximum damage values. These relationships are developed for a wide variety of residential, commercial and industrial buildings, using mostly synthetic analysis and expert judgment. Within each damage class, distinctive damage curves are available for different levels of physical building susceptibility (low-indicativehigh) and the presence of a basement. Since the calculated damage is aimed at representing national economic losses, all damage values are based on the pre-flood depreciated value of the affected properties.

Infrastructure losses are calculated in the MCM on the basis of observed traffic volumes on the affected road trajectory, the additional travel time and traffic cost per vehicle type. There are no damage functions to estimate physical damage to infrastructure. However, on the basis of empirical data from the 2007 floods, direct infrastructure recovery costs are estimated at $5.6 \%$ of property losses for urban and $10.7 \%$ for rural areas (J. Pardoe, personal communication, 2011). We used these generic figures in the present study.

The MCM describes the calculation of indirect flood damage as problematic (Penning-Rowsell et al., 2010, p. 38) and does not offer a generic methodology for such an assessment.For the benefit of mutual comparison with the other models, we have converted the absolute functions of the MCM to a relative system. In doing so we respected the maximum damage and proportional increase with depth, keeping the model outcomes unchanged.

Similar to HAZUS, the MCM is an object-based model, of which the maximum damage per square metre estimates only reflect expected repair costs to buildings and not damage to the surrounding land. From the available MCM categories 
we selected the classes that were considered to be most consistent with the classification of the other damage models and assigned them to the corresponding CORINE land use classes (Table 1). Again, we made a correction for the estimated surface area and density of buildings in each of the case study areas to generate an average maximum damage per square metre value for each CORINE class in both case studies (Table 2). As is the case for HAZUS, the CORINEadjusted maximum damage values are $61-88 \%$ lower than the original values.

\subsection{Rhine Atlas}

As a response to the 1995 floods in the Rhine basin, an Action Plan on Floods was agreed upon in 1998 to bundle all knowledge and measures, and to identify flood risk performance targets within the Rhine area (ICPR, 1998). In order to meet the performance targets in terms of risk reduction and flood awareness, the Rhine Atlas damage model (RAM) was developed (ICPR, 2001).

The RAM has the least detailed classification system of the models included in this study by recognising only five land use classes, three of which are attributed to built-up area. The depth-damage functions and the corresponding maximum damage values were established on the basis of the empirically based HOWAS flood damage database and expert judgement (ICPR, 2001). For the land use classes residential, industrial and infrastructure, the RAM applies both a structure and contents damage assessment. Since the RAM is developed to estimate direct economic costs, all damage values are calculated on the basis of depreciated values. Through a comparison with insurance data, the ICPR (2001) estimates that the replacement values are approximately a factor 2 higher than depreciated values. Indirect losses are not included in the RAM.

The relatively simple classification system of the RAM makes it easy to apply the model to case studies using CORINE land use data. We assigned the maximum damage values and depth-damage curves for residential areas to both continuous and discontinuous urban fabric in CORINE. As is the case with CORINE, the RAM contains a single class for industrial/commercial areas as well as one class for infrastructure.

\subsection{JRC Model}

In support of European policy on flood risk management, the European Commission's Joint Research Centre - Institute for Environment and Sustainability (JRC-IES) has developed a pan-European damage model (Huizinga, 2007), which has been applied to estimate trends in European flood risk under climate change (Ciscar et al., 2011; Feyen et al., 2012). In this paper, we refer to this as the JRC Model.
The JRC Model comprises differentiated depth-damage functions and maximum damage values for all EU-27 countries. Asset values are based on the CORINE land use data and are classified into five damage classes: residential, commercial, industrial, roads and agriculture. These damage classes are more specific than the original CORINE classes of continuous urban fabric, discontinuous urban fabric, industrial or commercial units and roads and rail networks and associated lands. An estimate is made of the relative breakdown of CORINE classes into the specific damage classes on the basis of the more detailed LUCAS photographic pointdatabase (European Commission, 2009). As a result, the flood depth in every grid cell is multiplied with a weighted average of depth-damage functions and maximum damage values. Depth-damage functions of nine countries were acquired from existing studies and applied to the corresponding damage classes. Where national studies were not available, an average of all available functions for the specific class was assigned. The average function is also applied when a country-specific function has a maximum relative damage factor of 0.6 or less, because in that case the maximum damage at even the highest water levels is reduced to such an extent that the function is considered invalid (Huizinga, 2007, p. 2-19).

Maximum damage values were collected from all EU countries for which this information could be found and damage functions were known. Subsequently, an average of these values was calculated for each of the damage classes, which can be applied to any EU-27 country or region, scaled to the GDP per capita. The administrative levels used were both country level and NUTS 2 level (800000 to 3 million inhabitants). Hence, the JRC damage functions are uniform within countries, whereas the maximum damage values can vary among regions within countries.

For the United Kingdom, Huizinga (2007) applied depthdamage functions based on Penning-Rowsell et al. (2005) and Van der Sande (2001). Maximum damage values for the Carlisle region were calculated using the average GDP per capita in the county Cumbria. For Germany, depth-damage functions were chosen using a combination of data from ICPR (2001), Apel et al. (2004), Meyer and Messner (2005), Büchele et al. (2006), Lindenschmidt et al. (2006) and Messner et al. (2007). Maximum damage values for Eilenburg were based on GDP figures from the Leipzig region.

As a result of the averaging of maximum damage values, the existing strong discrepancy that sometimes exists between maximum values across (adjacent) countries is reduced, but so is the consistency in these values to a certain extent. One reason for the reduction in consistency is that the average maximum damage values are made up of both depreciated and replacement values. Also, some of the maximum damage values include a percentage addition for indirect damage, while others do not. The JRC Model does not include a separate calculation of indirect effects. 
Table 3. Qualitative properties of the damage models included in this study, relating to their calculation of losses to residential, commercial and industrial units. A more extensive description of the models is provided in Sect. 4.

\begin{tabular}{|c|c|c|c|c|c|c|c|c|c|c|}
\hline $\begin{array}{l}\text { Damage } \\
\text { model }\end{array}$ & $\begin{array}{l}\text { Scale of ap- } \\
\text { plication }\end{array}$ & $\begin{array}{l}\text { Regional } \\
\text { differentia- } \\
\text { tion }\end{array}$ & $\begin{array}{l}\text { Units of } \\
\text { analysis }\end{array}$ & $\begin{array}{l}\text { Hydrological } \\
\text { characteris- } \\
\text { tics }\end{array}$ & $\begin{array}{l}\text { Data } \\
\text { method }\end{array}$ & $\begin{array}{l}\text { Number } \\
\text { of unit } \\
\text { classes }\end{array}$ & Cost base & $\begin{array}{l}\text { Empirical } \\
\text { valida- } \\
\text { tion }\end{array}$ & Function & Reference \\
\hline FLEMO & $\begin{array}{l}\text { Local } \\
\text { Regional } \\
\text { National }\end{array}$ & $\begin{array}{l}\text { Local asset } \\
\text { values }\end{array}$ & $\begin{array}{l}\text { Surface } \\
\text { area }\end{array}$ & $\begin{array}{l}\text { Depth Con- } \\
\text { tamination }\end{array}$ & Empirical & $5-10$ & $\begin{array}{l}\text { Replacement } \\
\text { values }\end{array}$ & Yes & Relative & $\begin{array}{l}\text { Thieken et al. (2008) } \\
\text { Kreibich et al. (2010) }\end{array}$ \\
\hline $\begin{array}{l}\text { Damage } \\
\text { Scanner }\end{array}$ & $\begin{array}{l}\text { Regional } \\
\text { National }\end{array}$ & No & $\begin{array}{l}\text { Surface } \\
\text { area }\end{array}$ & Depth & Synthetic & $5-10$ & $\begin{array}{l}\text { Replacement } \\
\text { values }\end{array}$ & No & Relative & Klijn et al. (2007) \\
\hline $\begin{array}{l}\text { Flemish } \\
\text { Model }\end{array}$ & $\begin{array}{l}\text { Regional } \\
\text { National }\end{array}$ & No & $\begin{array}{l}\text { Surface } \\
\text { area }\end{array}$ & Depth & Synthetic & $5-10$ & $\begin{array}{l}\text { Replacement } \\
\text { values }\end{array}$ & No & Relative & Vanneuville et al. (2006) \\
\hline $\begin{array}{l}\text { HAZUS- } \\
\text { MH }\end{array}$ & $\begin{array}{l}\text { Local } \\
\text { Regional }\end{array}$ & $\begin{array}{l}\text { Local asset } \\
\text { values }\end{array}$ & $\begin{array}{l}\text { Individual } \\
\text { objects } \\
\text { Surface } \\
\text { area }\end{array}$ & $\begin{array}{l}\text { Depth } \\
\text { Duration } \\
\text { Velocity } \\
\text { Debris } \\
\text { Rate of rise } \\
\text { Timing }\end{array}$ & $\begin{array}{l}\text { Empirical- } \\
\text { synthetic }\end{array}$ & $>20$ & $\begin{array}{l}\text { Replacement } \\
\text { values } \\
\text { Depreciated } \\
\text { values } \\
\text { (user's } \\
\text { choice) }\end{array}$ & Yes & Relative & FEMA (2009) \\
\hline MCM & $\begin{array}{l}\text { Local } \\
\text { Regional }\end{array}$ & No & $\begin{array}{l}\text { Individual } \\
\text { objects }\end{array}$ & Depth & Synthetic & $>20$ & $\begin{array}{l}\text { Depreciated } \\
\text { values }\end{array}$ & Limited & Absolute & $\begin{array}{l}\text { Penning-Rowsell et } \\
\text { al. (2010) }\end{array}$ \\
\hline Rhine Atlas & $\begin{array}{l}\text { Local } \\
\text { Regional }\end{array}$ & No & $\begin{array}{l}\text { Surface } \\
\text { area }\end{array}$ & Depth & $\begin{array}{l}\text { Empirical- } \\
\text { synthetic }\end{array}$ & $10-20$ & $\begin{array}{l}\text { Depreciated } \\
\text { values }\end{array}$ & No & Relative & ICPR (1998) \\
\hline JRC Model & $\begin{array}{l}\text { Regional } \\
\text { National } \\
\text { European }\end{array}$ & $\begin{array}{l}\text { GDP- } \\
\text { normalisation }\end{array}$ & $\begin{array}{l}\text { Surface } \\
\text { area }\end{array}$ & Depth & $\begin{array}{l}\text { Empirical } \\
\text { Synthetic } \\
\text { (Statistical) }\end{array}$ & $5-10$ & $\begin{array}{l}\text { Replacement } \\
\text { values } \\
\text { Depreciated } \\
\text { values } \\
\text { (averaged } \\
\text { values) }\end{array}$ & No & Relative & Huizinga (2007) \\
\hline
\end{tabular}

\section{Results and discussion}

\subsection{Qualitative assessment}

In Sect. 4 we presented a broad description of the seven flood damage models included in this study. A structured evaluation of the methodologies on the basis of the parameters defined in the qualitative framework (Fig. 3) is presented in Table 3. The results show that while all models are developed around depth-based flood damage assessment, there are strong differences in the approaches used. In this section we describe the main differences between the models that have an effect on the damage estimates, following the three aspects of the qualitative framework (Fig. 3).

\subsubsection{Object versus area based models}

An important division that can be recognised is between the object-based HAZUS and MCM models on the one hand, which use a large number of object types and corresponding flood damage characteristics, and the more aggregated surface area-based models on the other hand. The object-based models have the advantage that they can control for varying building density in areas that have the same CORINE land use class. At the same time, area-based models are used more easily for rapid calculation over larger areas and can be applied to scenario analysis (e.g. Klijn et al., 2007; Aerts et al., 2008; Aerts and Botzen, 2011).

\subsubsection{Regional differentiation}

Also, the models vary regarding the ability to apply spatial differentiation in their input parameters. The DSM, Flemish, RAM and MCM models have average parameters defined for each object or land use class, which are applied to their entire area of application (Netherlands, Belgium, the Rhine basin and the United Kingdom, respectively). FLEMO calculates damage using asset values differentiated on a municipality level, while applying the same depth-damage relationships to all areas. The HAZUS model accesses an extended US-wide database with asset values at the level of objects (e.g. important facilities, bridges) and census blocks (e.g. residential areas), in combination with a set of standard values for most object types. The same depth-damage functions are used nation-wide for the different types of objects. The JRC model differentiates maximum damage values on a NUTS 2 administrative level based on GDP per capita data, and depth-damage functions on the country level based on available studies. It can be expected that models that do not use regional differentiation will overestimate flood damage in the periphery, where values are low, and might underestimate losses in areas where values are higher than average.

\subsubsection{Input data}

A further difference relates to the data upon which the models are based. FLEMO has a strong empirical foundation, with reported damage data used both in the development and 
validation of the model. HAZUS and the Rhine Atlas are to a limited extent based on empirical data. The other models are almost purely synthetic, with maximum damage values and depth-damage curves developed using "what-if" analysis of the effect of simulated flood characteristics on different land use classes. Models based on empirical data could be more accurate when applied to a similar case study, but, as with synthetic models, the question remains whether data from a flood event in a certain location can be applied to another region or country (Green et al., 2011).

\subsubsection{Damage calculation}

Finally, we found that there is an important difference in methods for the valuation of assets at risk. FLEMO, DSM and the Flemish model value assets at replacement costs; MCM and RAM are based on depreciated values; the JRC model is a mixture of both; and HAZUS allows the user to choose which of the value types to use. Replacement values are interesting from an insurance perspective, since they provide information on the potential pay-outs involved. On the other hand, depreciated values are an estimated factor 2 lower than replacement values (e.g. ICPR, 1998) and give a better indication of the true economic costs associated with the (partial) loss of the asset (e.g. Penning-Rowsell et al., 2010). Given the big effect on the outcome, one should be aware of the type of valuation used in the model and choose a valuation based on the purpose of the analysis.

\subsection{Quantitative assessment}

\subsubsection{Damage estimates}

Table 4 shows that the modelled inundation zone in the Eilenburg study area is about three times as large as in the Carlisle area. Modelled flood depths vary strongly per location and land use class, with the average overall flood depth per grid cell being slightly higher in Eilenburg $(1.83 \mathrm{~m})$ than in Carlisle $(1.54 \mathrm{~m})$. Carlisle has more than twice as much total urban fabric in the inundated area than Eilenburg, $5 \%$ of which is classified as continuous urban fabric, a class not present in the Eilenburg area (Fig. 4). At the same time, Eilenburg has about $50 \%$ more inundated area classified as industrial and commercial units. Also, based on the vector infrastructure data that we added manually to the original CORINE data, we find the area classified as infrastructure to be greater by approximately a factor four in Eilenburg than in Carlisle.

The total estimated reported damage is approximately $145 \%$ higher in Carlisle than in Eilenburg, in spite of the fact that the inundated area is $220 \%$ smaller. The reported damage per square metre of the total inundated area is on average $€ 64$ in Eilenburg and $€ 497$ in Carlisle, a difference of a factor 7.8. The difference results from substantially higher losses from residential, commercial and industrial properties in Carlisle. Estimated infrastructural losses, on the other hand, are more than twice as high in Eilenburg.

For Eilenburg, the model estimates that show the strongest agreement with the reported damage are those from MCM and JRC. If we exclude the infrastructure component, which is not covered in all models, FLEMO, HAZUS and RAM are all within $50 \%$ error margins of the reported losses. The DSM and Flemish models strongly overestimate residential losses in Eilenburg. In Carlisle, on the other hand, all models strongly underestimate total losses. HAZUS and JRC show the strongest agreement both with and without the inclusion of infrastructure. The HAZUS and JRC models are also the only models that correctly simulate higher losses in Carlisle than Eilenburg (Fig. 7). The RAM strongly underestimates damage in both areas, which is in line with findings from earlier comparison studies (e.g. De Moel and Aerts, 2011; Bubeck et al., 2011).

\section{Relative distribution}

Figure 7 shows the magnitude of the modelled damage as well as the relative distribution over the residential, commercial/industrial and infrastructure classes. Note that FLEMO, HAZUS and MCM do not have depth-damage curves for infrastructure and thus do not include an estimate for this class. In both study areas, the reported residential damage is higher than commercial and industrial flood losses. Figure 7 shows that all models capture this. The same is not true for the estimation of infrastructure losses, which make up a significant share of the total damage in Eilenburg. Even with the complementary infrastructure data added to CORINE, all damage models that include this class strongly underestimate the corresponding losses in both case studies. This finding matches the general consensus that estimation of direct residential and commercial building damage is the best developed part of flood damage models, and is surrounded by less uncertainty than the estimation of infrastructure losses (Meyer and Messner, 2005; Merz et al., 2010; Green et al., 2011). At the same time, it is important to note that the DSM, Flemish, RAM and JRC models all include a component of local infrastructure as part of the asset values in residential areas. In these cases the infrastructure loss is represented in the damage estimates, but not distinguishable as a separate class.

\section{Object versus area based}

One reason why the reported damage is more than twice as high in Carlisle than in Eilenburg,whilst the area of the former is more than half that of the latter, is found in different building densities between the two areas. While the total area of urban fabric is a factor 3.7 times larger in Eilenburg $\left(2.2\right.$ million $\left.\mathrm{km}^{2}\right)$ than in Carlisle $\left(0.6\right.$ million $\left.\mathrm{km}^{2}\right)$, the reported total number of affected properties (765 vs. 1844) is a factor 2.4 lower. The Carlisle case study does have about $5 \%$ of its urban surface classified as continuous urban fabric 
Table 4. Results of the model runs for Carlisle and Eilenburg, with the inundation details on the left and the modelled and reported damages on the right. Further elaboration on the adjustment of damage model classes and reported damage data to the CORINE land use classes is provided in Sects. 3.2.1 and 3.2.2.

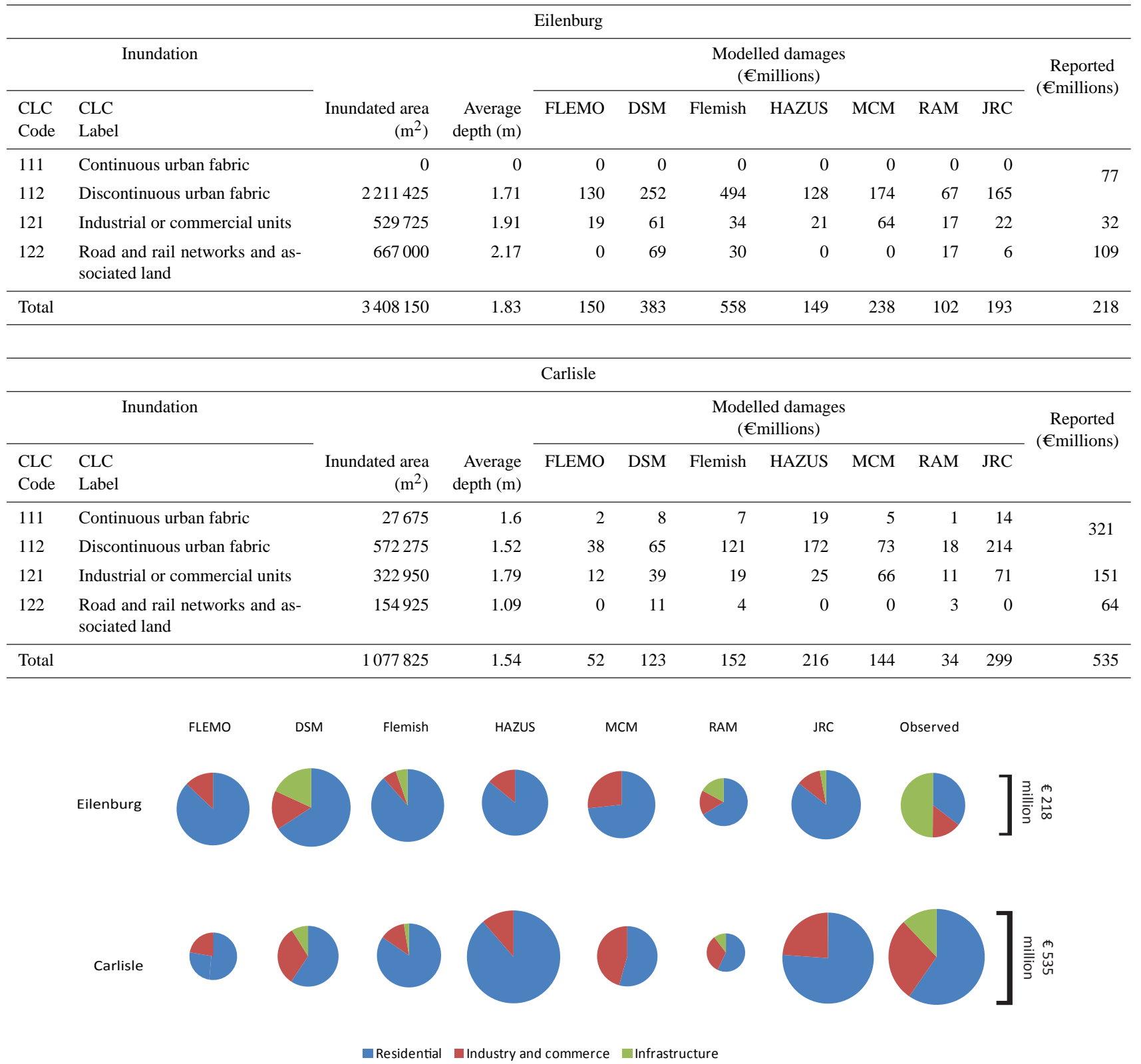

Fig. 7. Magnitude of estimated damages computed by the different models, and the corresponding break-down into individual land use classes. The corresponding numbers can be found in Table 4. Note that the simplified FLEMO, HAZUS and MCM models do not include specific estimates for infrastructure losses.

rather than discontinuous urban fabric whereas this land use class does not exist in Eilenburg, which is too little to explain the difference. The estimated damage to residential properties is $€ 77$ million in Eilenburg and $€ 321$ million in Carlisle, a factor 3.2 difference. Failing to correct for varying density within the same CORINE land use class irrevocably leads to higher damage estimates for the larger area of Eilenburg than Carlisle. Correspondingly, the density-adjusted version of HAZUS does correctly simulate higher losses for Carlisle. The MCM still estimates damage in Eilenburg to be higher than in Carlisle, but the difference is much smaller than without density correction. The JRC model also produces higher estimates for Carlisle than Eilenburg, due to the fact that it assigns a higher maximum damage value and a steeper curve 
to Cumbria than it does to Saxony (Fig. 6), which is unrelated to the density argument. These results show that care needs to be taken with aggregated land use data such as CORINE, which do not always accurately display local heterogeneity in object density and typology. Whether an object-based or area-based approach is more suited depends both on the scale of the study area and the quality of the land use data. Very small-scale studies in which the damage estimates of individual properties strongly affect the outcome would benefit from an object-based approach. On larger scales the local inaccuracies can be expected to average out to a certain extent. For the case study of Eilenburg, Apel et al. (2009) show that damage estimates on the basis of detailed aggregated land use data can be more accurate than object-based estimates. Our results confirm that area based approaches can deliver accurate results compared to reported flood losses, although adjusting for varying building density is advisable when working with CORINE land use data.

\section{Maximum damage values}

The factor 2.4 difference in the number of properties affected in Carlisle and Eilenburg, and related difference in building density, cannot fully explain the factor 3.2 difference in reported damage to residential, commercial and industrial properties. This remaining difference could plausibly result from the difference in asset values between the areas, for example in building and content values, which are shown to be directly related to GDP per capita and economic activity (Green, 2010). We clearly observe that the JRC damage model, which specifies maximum damage values on the basis of GDP per capita at NUTS 2 administrative level, best captures this variation. The FLEMO model applies maximum damage values based on Eilenburg asset values, and accordingly gives a very good estimate of Eilenburg damage but too low estimates in Carlisle where higher maximum damage values seem to be more representative.

Also, it is important to note the effect of valuing assets at either depreciated or replacement costs. The RAM, which is based on depreciated values, substantially underestimates losses in both case studies. Multiplying its outcomes with a factor 2, which is estimated by ICPR (1998) to be the approximate difference between replacement and depreciated values, indeed gives a simulated damage that is much closer to the reported losses in Eilenburg. In Carlisle, however, the RAM would still give the lowest estimates, on par with FLEMO, even after the factor 2 increase in maximum damage values. The MCM is also based on depreciated values, but still overestimates residential and commercial/industrial losses in Eilenburg. In Carlisle the MCM estimates are average compared to the other models, but low compared to reported damage. Thus, overall we cannot identify a clear pattern between models using replacement or depreciated values.

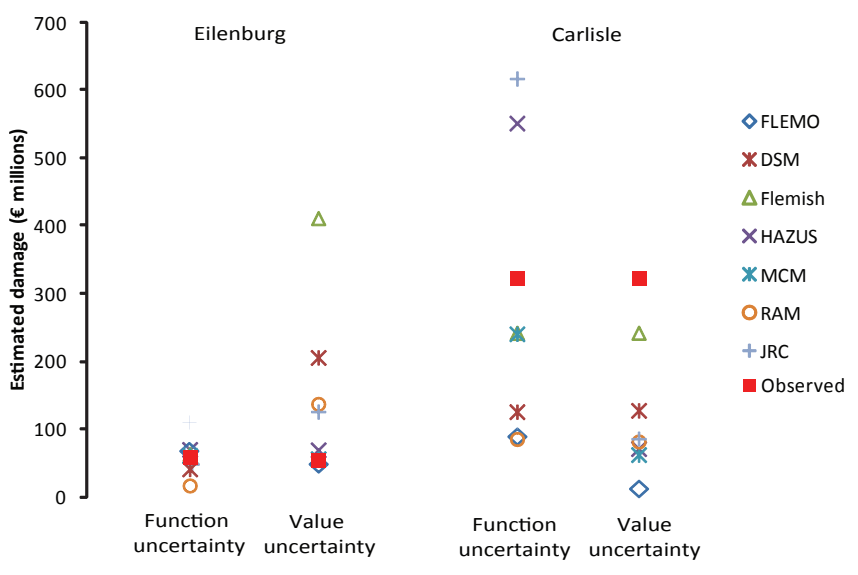

Fig. 8. Sensitivity of the model outcomes to changes in depthdamage functions and maximum damage values, residential areas (CLC 111 and 112). Function uncertainty is shown by keeping a constant maximum damage value ( $€ 100$ for Eilenburg, $€ 800$ for Carlisle) while using the various depth-damage functions from all models. Value uncertainty is shown by keeping a constant depthdamage function (FLEMO for Eilenburg, MCM for Carlisle) while applying the various maximum damage values.

\subsubsection{Sensitivity analysis}

We conducted a sensitivity analysis to identify the effect of the applied depth-damage functions on the one hand, and the corresponding maximum damage values on the other. Figure 8 shows the results for uncertainty in residential damage. We visualised function uncertainty by keeping one fixed maximum damage value while applying the different depthdamage functions. For both case study areas, we manually chose the "median" maximum damage value that resulted in a distribution of model outcomes around the reported flood damage in each case study (Fig. 8). The applied maximum damage values are $€ 100$ for Eilenburg and $€ 800$ for Carlisle. The large difference in "median" value results from the discrepancy in average reported damage per square metre, which is a factor 7.8 higher in Carlisle than in Eilenburg (see Sect. 5.2.1). Value uncertainty is shown by combining fixed depth-damage functions with the different maximum damage values. We applied the depth-damage functions developed for the respective countries - for Carlisle we used the MCM and for Eilenburg the FLEMO functions.

Figure 8 shows that both function and value uncertainties have a strong influence on the simulated results. Depending on the input functions and maximum damage values, modelled damage varies between $€ 55-€ 472$ million in Eilenburg, and €32-€612 million in Carlisle. The relative difference between the highest and lowest estimates is a factor 7.4 for value uncertainty in both study areas. For function uncertainty, the differences are a factor 3.7 in Eilenburg and 10.5 in Carlisle. This is higher than the factor 2 for both function and value uncertainty as found by De Moel and Aerts (2011). 
Table 5. Results for function uncertainty and value uncertainty for Eilenburg and Carlisle. Function uncertainty is calculated by keeping a constant maximum damage value while using the various depth-damage functions from all models. Value uncertainty is calculated by keeping a constant depth-damage function while applying the various maximum damage values (Fig. 8). Absolute uncertainty is calculated by subtracting the lowest from the highest model estimate, while relative uncertainty is obtained by dividing the lowest by the highest estimate.

\begin{tabular}{lrrrrrr}
\hline & \multicolumn{2}{c}{ Function uncertainty } & & \multicolumn{2}{c}{ Value uncertainty } \\
\cline { 2 - 3 } \cline { 5 - 6 } & $\begin{array}{r}\text { Absolute } \\
(€ \text { millions })\end{array}$ & Relative & & $\begin{array}{r}\text { Absolute } \\
(€ \text { millions })\end{array}$ & Relative \\
\hline Eilenburg & 72 & 3.7 & & 356 & 7.4 \\
Carlisle & 554 & 10.5 & & 210 & 7.4 \\
\hline
\end{tabular}

The reason for the difference is that their study only includes the Damage Scanner, Flemish and RAM, while our comparison includes models that produce both lower and higher estimates.For the same reason, our estimate for function uncertainty is slightly higher than the factor $4-8$ found by De Moel et al. (2012), who computed this using Monte Carlo analysis of the input variables of the DSM.

\section{Function uncertainty}

The difference between the highest and lowest damage estimates (Table 5) shows that absolute function uncertainty is larger in Carlisle than in Eilenburg. Moreover, the relative function uncertainty, calculated by dividing the highest estimate by the lowest one for each case study, is also larger. This indicates that the same maximum damage value leads to a larger relative spread of modelled damage in Carlisle than in Eilenburg.The explanation can be found in the flood depth histogram (Fig. 4) and the shape of the damage functions (Fig. 1). Figure 5 shows that about $10 \%$ of the inundated grid cells in the Carlisle study area are inundated with flood depths between 0 and $1 \mathrm{~m}$, compared to only around $5 \%$ in Eilenburg. Figure 9 shows that the relative difference between the highest and lowest depth-damage functions is considerably larger in this depth range than in any other range. The relative difference declines with depth for inundation above $80 \mathrm{~cm}$. Uncertainty in depth-damage functions thus leads to a larger relative spread of model outcomes in study areas with low inundation depths. Theoretically, a flood event in which inundation is homogenously constant at around $0.5 \mathrm{~m}$ could result in a function uncertainty of a factor $40-50$.

In terms of uncertainty assessment, this result implies that propagation of uncertainty in different parts of the applied relative depth-damage function varies on a case-to-case basis with differences in depth-frequency histograms. Hence, if models are to be applicable to a wide range of potential flood events, close attention has to be paid to all sections of the depth-damage function.

\section{Value uncertainty}

We assessed value uncertainty using one constant depthdamage function, and it therefore only shows disparity in absolute variation in damage model estimates between both case study areas. In other words, changing the maximum damage value while using the same curve affects the absolute spread in model outcomes, but the relative difference between the highest and lowest model estimates remains the same. This relative difference is a factor 7.4 in both Eilenburg and Carlisle. In absolute terms, the value uncertainty results show the opposite pattern to function uncertainty (Fig. 8; Table 5). The larger inundated surface area in Eilenburg causes a stronger effect of variation in model outcomes. In particular, the greater amount of residential area (to which most damage models assign the highest maximum value) results in a considerable spread. In addition, the number of grid cells inundated with a higher flood depth (e.g. $>2 \mathrm{~m}$ ) is relatively larger in Eilenburg than in Carlisle (Fig. 5), which means that maximum damage values are approached more often in Eilenburg. The effect of the larger inundation depth on damage estimates is amplified by the shape of the damage functions used for both case studies, FLEMO (Eilenburg) and MCM (Carlisle) (Fig. 6). The FLEMO residential depthdamage curve approaches its maximum at around $1.5 \mathrm{~m}$ inundation. Hence, in combination with Fig. 5, we see that maximum damage applies for approximately $90 \%$ of the inundated area when applying FLEMO. The depth-damage curve of the MCM model only reaches its maximum at $3 \mathrm{~m}$, which means that maximum damage applies for only circa $35 \%$ of the inundated cells in Carlisle.

The results emphasise that absolute uncertainty in asset values propagates relative to the size of the inundated surface area, assuming the difference between the maximum damage per square metre value assumed in the model and the real maximum damage value is similar over space. Models applying the same asset values to a number of economically distinct regions, even if this asset value is a good estimate on average, may thus substantially over or underestimate absolute flood losses. FLEMO, HAZUS and the JRC Model incorporate regional differentiation of asset values in their approach, while the DSM, Flemish Model, RAM and the MCM do not.

\section{Comparison}

Relative value uncertainty is dependent on the maximum damage values chosen in the damage models and thus varies within those boundaries. In contrast, function uncertainty depends on the frequency histogram of inundation depths and could reach a factor 40-50. Thus, sensitivity of modelled flood damage estimates to uncertainty in depth-damage 


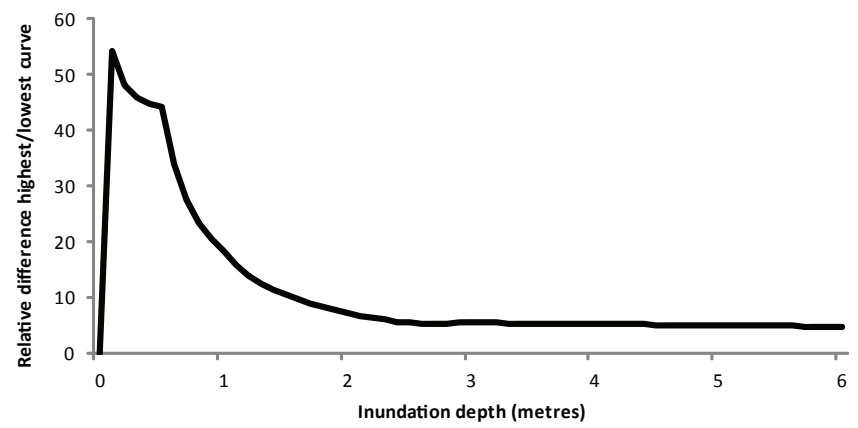

Fig. 9. Relative differences between the highest and lowest relative depth-damage functions for depths between 0 and $6 \mathrm{~m}$. For example, for a depth of $0.5 \mathrm{~m}$, the lowest value is $1.5 \%$ of maximum damage (Rhine Atlas Model) and the highest value $66 \%$ (JRC Model), a relative difference of a factor 43 .

functions is higher than to uncertainty in maximum damage values. This is in line with findings of De Moel et al. (2012), who carried out a sensitivity analysis on the basis of statistical uncertainty bounds around the DSM.

The strong effect of both types of uncertainty emphasise the spatial heterogeneity of exposure values and vulnerability on the basis of which the different flood damage models have been developed. The results concur with findings by Green et al. (2011), who argue that exposure values are directly related to GDP per capita. However, the results of the JRC model, in which the difference in exposure values between Carlisle and Eilenburg is indeed based on a function of GDP, show that only correcting for this factor does not lead to a satisfactory result for each land use class. This stresses that there are other factors influencing local vulnerability and exposure - such as predominant building style, household income, regulations, and flood insurance practice - which may cause discrepancies when applying damage models outside of their region of development.

\section{Conclusions and recommendations}

In this paper we have compared seven flood damage models on their documented properties as well as their quantitative performance in two case studies. We observe significant differences between the models that are clearly translated in the model outcomes. The comparison provides valuable insights for the development of a sophisticated pan-European damage modelling framework.

First of all, care needs to be taken with the input land use data on which to base the damage modelling.The results show that in the case of relatively small study areas, local heterogeneity in the density of objects within the same land use class can have a strong effect on the damage estimates. Thus, when using aggregated area-based data such as CORINE, adjustments should be made to account for varying density of assets within areas classified as the same land use type, to prevent strong over or underestimation of flood damage. Where possible, a sensitivity analysis of the effect of using either aggregated or object-based land use data and damage models can assist with getting a grip on the spatial consistency of the land use data.

Also, we noticed that the original CORINE land use data did not report any infrastructure and associated land in either of the two case study areas used in this study, while damage to infrastructure made up a significant share of reported losses. We added roads and railways using an additional data source. Spatial infrastructure databases are available with improving precision on an increasingly large scale (e.g. PBL, 2011), and are already applied successfully in global land use and accessibility studies (e.g. Verburg et al., 2011). However, our comparison results also show that even with the additional infrastructure information, current methodologies still underestimate losses to this land use class, which is in line with findings from earlier studies (e.g. Meyer and Messner, 2005; Merzet al., 2010). Since infrastructure losses can make up a large share of total losses (e.g. Bubeck et al., 2011), it should be a future research priority to identify the damage inflicting factors and establish methodologies for accurate damage assessment. We also note that the analysis in this study has been limited to the sensitivity of damage models that use depth as main damage determining parameter. Kreibich et al. (2009) have shown that flow velocity can have a strong impact on infrastructure damages, which contributes further to the uncertainty surrounding the damage assessment.

Furthermore, our study emphasises the need for respecting the regional variation in asset values. The relevance of spatial differentiation has been shown by the regionally validated FLEMO model, which performs very well in Eilenburg but not in Carlisle. Also, the case study results show that the first European model developed for the European Commission's Joint Research Centre (Huizinga, 2007) produces estimates that are relatively close to the reported damage in both case studies. Both models apply regional differentiation of asset values, either on the basis of GDP per capita data at NUTS 2 administrative level (JRC Model) or reparation cost data at municipality level (FLEMO). GDP has been shown to be directly related to asset values (Green, 2010), but this relationship can be distorted substantially in countries that are largely dependent on natural resources or those with large internal income inequality (e.g. Jongman et al., 2012). Also, only correcting for GDP does not take into account other factors influencing exposure and vulnerability differences between regions, such as building style, household income, regulations and insurance practice. We therefore propose that a new European methodology differentiates maximum damage values and vulnerability functions based on an informed selection of such aspects.

Similar to previous findings by De Moel et al. (2012), our sensitivity analysis shows that uncertainty in depthdamage curves can affect the resulting damage estimates 
more strongly than uncertainty in the applied maximum damage values.Because we applied a larger variety of damage models, our estimates of function uncertainty (factor 4-11) are slightly higher than those found by De Moel et al. (factor 4-8). The effect of uncertainty due to the shape of depthdamage functions as well as the maximum damage values is shown to be dependent on the inundation depth pattern of the flooded area. Since uncertainty in depth-damage functions has a large effect on the outcome, and given that the functions describe local asset characteristics, we also propose differentiation in this respect. The JRC Model currently does this on the basis of available national studies and by assigning an average curve to countries for which no study is available. We propose a more advanced differentiation on the basis of observable factors such as assumed building material, type, quality and age, and the average value of content compared to structure value, in combination with artificial inundation scenarios, expert judgement and an improving empirical damage database.

Finally, it is worth noting the increasing attention to flood damage modelling methods that reach beyond the European level. Global scale flood risk assessments are, for example,included in recent reports of international organisations such as the UNISDR (UNISDR, 2011) and IPCC (IPCC, 2012), and financing institutions like the World Bank (Jha et al., 2012) and Munich Re (Munich Re, 2010). Even though data availability on a global scale is more limited than on the European level, the recommendations resulting from this study are also applicable to the development of a global flood risk framework.

Acknowledgements. We are grateful to Hans De Moel, David Demeritt and one anonymous referee for their comments on earlier drafts of this paper. This research was conducted as part of the Climate Proof Flood Risk Management theme within the Knowledge for Climate programme; and part of a VENI project granted by the Netherlands Organisation for Scientific Research (NWO).

Edited by: M.-C. Llasat

Reviewed by: D. Demeritt and one anonymous referee

\section{References}

ADB and The World Bank: "Pakistan floods 2010: Preliminary damage and needs assessment", Asian Development Bank, Islamabad, 2010.

Aerts, J. C. J. H. and Botzen, W. J.: Climate Change Impacts on Long-Term Flood Risk and Insurance: A Comprehensive Study for The Netherlands, Global Environ. Chang., 21, 1045-1060, doi:10.1016/j.gloenvcha.2011.04.005, 2011.

Aerts, J. C. J. H., Botzen, W. J., Van der Veen, A., Krykrow, J., and Werners, S.: Portfolio management for developing Flood Protection measures, Ecol. Soc., 13, available at: www. ecologyandsociety.org/vol13/iss1/art41, 2008.
Apel, H., Thieken, A. H., Merz, B., and Blöschl, G.: Flood risk assessment and associated uncertainty, Nat. Hazards Earth Syst. Sci., 4, 295-308, doi:10.5194/nhess-4-295-2004, 2004.

Apel, H., Merz, B., and Thieken, A. H.: Quantification of uncertainties in flood risk assessments, Int. J. River Basin Manage., 6, 149-162, 2008.

Apel, H., Aronica, G. T., Kreibich, H., and Thieken, A. H.: Flood risk analyses-how detailed do we need to be?, Nat. Hazards, 49, 79-98, 2009.

Barredo, J. I.: Normalised flood losses in Europe: 1970-2006, Nat. Hazards Earth Syst. Sci., 9, 97-104, doi:10.5194/nhess-9-972009, 2009.

Barredo, J. I. and De Roo, A.: Flood damage functions for EU member states. Flood risk mapping using Corine land cover datasets, CONHAZ Project Presentation, Ghent, 2010.

Barredo, J. I., Saurí, D., and Llasat, M. C.: Assessing trends in insured losses from floods in Spain 1971-2008, Nat. Hazards Earth Syst. Sci., 12, 1723-1729, doi:10.5194/nhess-12-17232012, 2012.

Bates, P. D., Horritt, M. S., and Fewtrell, T. J.: A simple inertial formulation of the shallow water equations for efficient two dimensional flood inundation modelling, J. Hydrol., 387, 33-45, doi:10.1016/j.jhydrol.2010.03.027, 2010.

Bouwer, L. M., Bubeck, P., and Aerts, J. C. J. H.: Changes in future flood risk due to climate and development in a Dutch polder area, Global Environ. Chang., 20, 463-471, 2010.

Briene, M., Koppert, S., Koopman, A., and Verkennis, A.: Financiële onderbouwing kengetallen hoogwaterschade, Netherlands Economic Institute (NEI), Rotterdam, the Netherlands, I7435, 2002.

Bubeck, P. and Kreibich H.: Natural Hazards: direct costs and losses due to the disruption of production processes, ConHaz report D1.2, available at: http://conhaz.org/project/cost-assessment-work-packages/ wp1-8-final-reports/CONHAZREPORTWP01 \2.pdf (last access: 11 May 2011), 2011

Bubeck, P., De Moel, H., Bouwer, L. M., and Aerts, J. C. J. H.: How reliable are projections of future flood damage?, Nat. Hazards Earth Syst. Sci., 11, 3293-3306, doi:10.5194/nhess-11-32932011, 2011.

Büchele, B., Kreibich, H., Kron, A., Thieken, A., Ihringer, J., Oberle, P., Merz, B., and Nestmann, F.: Flood-risk mapping: contributions towards an enhanced assessment of extreme events and associated risks, Nat. Hazards Earth Syst. Sci., 6, 485-503, doi:10.5194/nhess-6-485-2006, 2006.

Ciscar, J.-C., Iglesias, A., Feyen, L., Szabó, L., Van Regemorter, D., Amelung, B., Nicholls, R., Watkiss, P., Christensen, O. B., Dankers, R., Garrote, L., Goodess, C. M., Hunt, A., Moreno, A., Richards, J., and Soria, A.: Physical and economic consequences of climate change in Europe, Proc. Nat. Aca. Sci. USA, 108, 2678-2683, 2011.

Charnwood Borough Council: "Anstey flood allevation scheme: project appraisal report", Borough of Charnwood, Loughborough, 2003.

Day, A. L.: Carlisle storms and associated flooding: Multi-agency debrief report, UK Resilience, 2005.

De Moel, H. and Aerts, J. C. J. H.: Effect of uncertainty in land use, damage models and inundation depth on flood risk estimates, Nat. Hazards, 58, 407-425, 2011. 
De Moel, H., Aerts, J. C. J. H., and Koomen, E.: Development of flood exposure in the Netherlands during the 20th and 21st century, Global Environ. Chang., 21, 620-627, 2011.

De Moel, H., Asselman, N. E. M., and Aerts, J. C. J. H.: Uncertainty and sensitivity analysis of coastal flood damage estimates in the west of the Netherlands, Nat. Hazards Earth Syst. Sci., 12, 10451058, doi:10.5194/nhess-12-1045-2012, 2012.

De Roo, A., Barredo, J. I., Lavalle, C., Bodis, K., and Bonk, R.: Potential flood hazard and risk mapping at pan-European scale, in: Digital Terrain Modelling - Development and Applications in a Policy Support Environment, edited by: Peckham, R. and Jordan, G., Springer, 2007.

Ding, A., White, J. F., Ullman, P. W., and Fashokun, A. O.: Evaluation of HAZUS-MH Flood Model with Local Data and Other Program, Nat. Hazards Rev., 9, 1-9, 2008.

EA: The costs of the summer 2007 floods in England, Environment Agency, Bristol, SC070039/R1, 2010.

EEA: CORINE land cover 2006 (CLC2006) 100 m, [112/2009], Copenhagen, Denmark, European Environment Agency, 2009.

Elmer, F., Thieken, A. H., Pech, I., and Kreibich, H.: Influence of flood frequency on residential building losses, Nat. Hazards Earth Syst. Sci., 10, 2145-2159, doi:10.5194/nhess-10-21452010, 2010.

ESRI: ESRI Data andMaps [9.3.1], ESRI ArcGIS, 2009.

European Commission: Land Use and Cover Area frame Survey (LUCAS), available at: http://epp.eurostat.ec.europa.eu/portal/ page/portal/lucas/introduction (last access: 12 December 2011), 2009.

European Commission: Eurostat Statistics, available at: http: //epp.eurostat.ec.europa.eu/portal/page/portal/statistics/themes (last access: 14 May 2012), European Commission, Brussels, 2012.

European Council: Council regulation (EC) No 2012/2002, establishing the European Union Solidarity Fund, 2012/2002, 2002.

European Parliament: Directive 2007/60/EC of the European Parliament and of the Council on the assessment and management of flood risk, 2007/60/EC, 2007.

FEMA: HAZUS-MH MR4 Flood Model Technical Manual, Federal Emergency Management Agency, Mitigation Division, Washington, DC, 2009.

FEMA Region IV: Using HAZUS for Flood Loss Estimates and CRS Flood Mitigation Plans, 2008.

FEMA Region VII: Johnson County Emergency Management and Homeland Security Collaborates with the University of Iowa Department of Geography to Assess Flooding Impacts Using HAZUS-MH, 2008.

Fewtrell, T. J., Neal, J. C., Bates, P. D., and Harison, P. J.: Geometric and structural river channel complexity and the prediction of urban inundation, Hydrol. Process., 25, 3173-3186, 2011.

Feyen, L., Dankers, R., Bódis, K., Salamon, P., and Barredo, J. I.: Fluvial flood risk in Europe in present and future climates, Climatic Change, 112, 47-62, doi:10.1007/s10584-011-0339-7, 2011.

Freni, G., La Loggia, G., and Notaro, V.: Uncertainty in urban flood damage assessment due to urban drainage modelling and depthdamage curve estimation, Water Sci. Technol., 61, 2979-2993, 2010.

Giron, E., Joachain, H., Degroof, W., Hecq, W., Coninc, I., Bachus, K., Dewals, B. J., Ernst, J., Pirotton, M., Staes, J., Meire, P., de Smet, L., and de Sutter, R.: Towards an integrated decision tool for adaptation measures - case study: Floods "ADAPT" $\mathrm{SD} / \mathrm{CP} / 02,2010$.

Green, C. H.: Coastal cities: assets at risk and depth-damage curves; report prepared for the OECD, Middlesex University, 2010.

Green, C. H., Viavattene, C., and Thompson, P.: Guidance for assessing flood losses: CONHAZ report, Flood Hazard Research Centre - Middlesex University, Middlesex, WP6 Report, 2011.

Hall, J. W., Tarantola, S., Bates, P. D., and Horritt, M. S.: Distributed sensitivity analysis of flood inundation model calibration, J. Hydraul. Eng., 131, 117-126, 2005.

Hochrainer, S., Linnerooth-Bayer, J., and Mechler, R.: The European Union Solidarity Fund.Its legitimacy, viability and efficiency, Mitigation Adapt. Strat. Glob. Chang., 15, 797-810, 2009.

Horritt, M., Bates, P. D., Fewtrell, T. J., Mason, D., and Wilson, M. D.: Modelling the hydraulics of the Carlisle 2005 flood event, Proc. Inst. Civil Eng., 163, 273-281, 2010.

Huizinga, H. J.: Flood damage functions for EU member states, HKV Consultants, Implemented in the framework of the contract \#382442-F1SC awarded by the European Commission - Joint Research Centre, 2007.

ICPR: International Commission for the Protection of the Rhine, Action Plan on Flood Defence, International Commission for the Protection of the Rhine, Koblenz, 1998.

ICPR: Atlas of flood danger and potential damage due to extreme floods of the Rhine, International Commission for the Protection of the Rhine, Koblenz, 2001.

IPCC: Managing the Risks of Extreme Events and Disasters to Advance Climate Change Adaptation. A Special Report of Working Groups I and II of the Intergovernmental Panel on Climate Change, edited by: Field, C. B., Barros, V., Stocker, T. F., Qin, D., Dokken, D. J., Ebi, K. L., Mastrandrea, M. D., Mach, K. J., Plattner, G.-K., Allen, S. K., Tignor, M., and Midgley, P. M., Cambridge University Press, Cambridge, UK, and New York, NY, USA, 582 pp., 2012.

Jha, A. K., Bloch, R., and Lamond, J.: Cities and flooding: a guide to integrated urban flood risk management for the 21st century, The World Bank, Washinton DC, 2012.

Jongman, B., Aerts, J. C. J. H., and Aerts, P. J.: Global scale flood risk assessment: methodologies and results, presented at European Geosciences Union General Assembly, EGU General Assembly, EGU2012-7533, Vienna, 22-27 April, 2012.

Jonkman, S. N.: Global perspectives of loss of human life caused by floods, Nat. Hazards, 34, 151-175, 2005.

Kelman, I. and Spence, R.: An overview of flood actions on buildings, Eng. Geol., 73, 297-309, 2004.

Kind, J.: Maatschappelijke kosten-batenanalyse Waterveiligheid 21e eeuw, Deltares, Delft, 2011.

Kleist, L., Thieken, A. H., Köhler, P., Müller, M., Seifert, I., Borst, D., and Werner, U.: Estimation of the regional stock of residential buildings as a basis for a comparative risk assessment in Germany, Nat. Hazards Earth Syst. Sci., 6, 541-552, doi:10.5194/nhess-6-541-2006, 2006.

Klijn, F., Baan, P. J. A., De Bruijn, K. M., and Kwadijk, J.: Overstromingsrisico's in Nederland in een veranderend klimaat, WL delft hydraulics, Delft, Netherlands, Q4290, 2007.

Kok, M., Huizinga, H. J., Vrouwenvelder, A. C. W. M., and Barendregt, A.: Standaardmethode 2004 - Schade en Slachtoffers 
als gevolg van overstromingen, RWS Dienst Weg-en Waterbouwkunde, DWW-2005-005, 2005.

Kreft, M.: Quantifying the impacts of climate related natural disasters in Australia and New Zealand, Munich Re, Wellington, 2011.

Kreibich, H. and Thieken, A.: Assessment of damage caused by high groundwater inundation, Water Resour. Res., 44, W09409, doi:10.1029/2007WR006621, 2008.

Kreibich, H., Müller, M., Thieken, A., and Merz, B.: Flood precaution of companies and their ability to cope with the flood in August 2002 in Saxony, Germany, Water Resour. Res., 43, W03408, doi:10.1029/2005WR004691, 2007.

Kreibich, H., Piroth, K., Seifert, I., Maiwald, H., Kunert, U., Schwarz, J., Merz, B., and Thieken, A. H.: Is flow velocity a significant parameter in flood damage modelling?, Nat. Hazards Earth Syst. Sci., 9, 1679-1692, doi:10.5194/nhess-9-1679-2009, 2009.

Kreibich, H., Seifert, I., Merz, B., and Thieken, A. H.: Development of FLEMOcs - A new model for the estimation of flood losses in companies. Hydrological Sciences Journal, J. Sci. Hydrol., 55, 1302-1314, 2010.

Kreibich, H., Meyer, S., and Diekkrüger, B.: Weiterentwicklung von FLEMOps zur Modellierung von Grundhochwasserschäden und Wohngebäuden, Hydrol. Wasserbewirt., 55, 300-309, $2011 \mathrm{a}$.

Kreibich, H., Seifert, I., Thieken, A. H., Lindquist, E., Wagner, K., and Merz, B.: Recent changes in flood preparedness of private households and businesses in Germany, Regional Environ. Change, 11, 59-71, $2011 \mathrm{~b}$.

Kuhlicke, C.: Ignorance and Vulnerability - the 2002 Mulde Flood in the City of Eilenburg, PhD Thesis, Department of Geography, University of Potsdam, 2008.

Leitstelle Wiederaufbau: Augusthochwasser 2002 - Schadenausgleich und Wiederaufbau im Freistaat Sachsen Sächsische Staatskanzlei, Dresden, 2003.

Lindenschmidt, K.-E., Herrmann, U., Pech, I., Suhr, U., Apel, H., and Thieken, A.: Risk assessment and mapping of extreme floods in non-dyked communities along the Elbe and Mulde Rivers, Adv. Water Resour., 9, 15-23, 2006.

Lugeri, N., Genovese, E., Lavalle, C., and De Roo, A.: Flood risk in Europe: analysis of exposure in 13 countries, European Commission Directorate-General Joint Research Centre, EUR22525 EN, 2006.

Mason, D. C., Horritt, M. S., Hunter, N. M., and Bates, P. D.: Use of fused airborne scanning laser altimetry and digital map data for urban flood modelling, Hydrol. Process., 21, 1436-1447, 2007.

Merz, B., Kreibich, H., Thieken, A., and Schmidtke, R.: Estimation uncertainty of direct monetary flood damage to buildings, Nat. Hazards Earth Syst. Sci., 4, 153-163, doi:10.5194/nhess-4-1532004, 2004.

Merz, B., Kreibich, H., Schwarze, R., and Thieken, A.: Review article "Assessment of economic flood damage", Nat. Hazards Earth Syst. Sci., 10, 1697-1724, doi:10.5194/nhess-10-16972010, 2010.

Messner, F., PennningRowsell, E. C., Green, C., Meyer, V., Tunstall, S. M., and van der Veen, A.: Evaluating flood damages: guidance and recommendations on principles and methods, FLOODsite, Wallingford, UK, T09-06-01, 2007.

Meyer, V. and Messner, F.: National Flood Damage Evaluation Methods - a review of applied methods in England, the Nether- lands, the Czech Republic and Germany, Department of Economics, Umweltforschungszentrum Leipzig-Halle, Leipzig, Germany, 21/2005, 2005.

Meyer, V., Scheuer, S., and Haase, D.: A multicriteria approach for flood risk mapping exemplified at the Mulde river, Germany, Nat. Hazards, 48, 17-39, 2009.

Munich Re: Topics Geo, natural catastrophes: analyses, assessments, positions, Munich Reinsurance Company, Munich, Germany, 2009, 2010.

Neal, J. C., Bates, P. D., Fewtrell, T. J., Hunter, N. M., Wilson, M. D., and Horrit, M. S.: Distributed whole city water level measurements from the Carlisle 2005 urban flood event and comparison with hydraulic model simulations, J. Hydrol., 368, 42-55, 2009.

Neal, J., Keef, C., Bates, P., Beven, K., and Leedal, D. Probabilistic flood risk mapping including spatial dependence, Hydrol. Process., doi:10.1002/hyp.9572, online first, 2012.

Nicholas, J., Holt, G. D., and Proverbs, D.: Towards standardizing the assessment of flood damaged properties in the UK, Struct. Survey, 19, 163-172, 2001.

Office for National Statistics: Census 2001: General Report for England and Wales, Palgrave Macmillan, Basingstoke, Hampshire, 2005.

Office for National Statistics: UK National Statistics, available at: http://www.statistics.gov.uk/hub/index.html (last access: 11 December 2011), 2012.

PBL: GRIP: Global Roads Inventory Project, Planbureau voor de Leefomgeving, Bilthoven, 2011.

Pech, I., Apel, H., Thieken, A. H., and Lindenschmidt, K.-E.: Unsicherheiten in der Hochwasserrisikoanalyse am Beispiel der Gemeinden Döbeln und Eilenburg an der Mulde/Sachsen, GWF Wasser Abwasser, 149, 53-63, 2008.

Pennning-Rowsell, E. C. and Chatterton, J. B.: The benefits of flood allevation: A manual of assessment techniques Saxon House, Farnborough, 1977.

Pennning-Rowsell, E. C., Green, C. H., Thompson, P. M., Coker, A. M., Tunstall, S. M., Richards, C., and Parker, D. J.: The economics of coastal management: a manual of benefit assessment techniques, DEFRA, London, 1992.

Penning-Rowsell, E. C., Johnson, C., Tunstall, S., Tapsell, S., Morris, J., Chatterton, J., and Green, C.: The benefits of flood and coastal risk management: a handbook of assessment techniques, Flood Hazard Research Centre, Middlesex University Press, 2005.

Penning-Rowsell, E., Viavattene, C., Pardoe, J., Chatterton, J., Parker, D., and Morris, J.: The Benefits of Flood and Coastal Risk Management: A Handbook of Assessment Techniques, Flood Hazard Research Centre, Middlesex, 2010.

Poussin, J. K., Bubeck, P., Aerts, J. C. J. H., and Ward, P. J.: Potential of semi-structural and non-structural adaptation strategies to reduce future flood risk: case study for the Meuse, Nat. Hazards Earth Syst. Sci., 12, 3455-3471, doi:10.5194/nhess-123455-2012, 2012.

Scawthorn, C., Flores, P., Blais, N., Seligson, H., Tate, E., Chang, S., Mifflin, E., Thomas, W., Murphy, J., Jones, C., and Lawrence, M.: HAZUS-MH flood loss estimation methodology, II. Damage and loss assessment, Nat. Hazards Rev., 7, 72-81, 2006.

Schwarz, J., Maiwald, H., and Gerstberger, A.: Quantifizierung der Schäden infolge Hochwassereinwirkung: Fallstudie Eilenburg, Bautechnik, 82, 845-856, 2005. 
Seifert, I., Kreibich, H., Merz, B., and Thieken, A. H.: Application and validation of FLEMOcs - a flood loss estimation model for the commercial sector. Hydrological Sciences Journal, J. Sci. Hydrol., 55, 1315-1324, 2010a.

Seifert, I., Thieken, A. H., Merz, M., Borst, D., and Werner, U.: Estimation of industrial and commercial asset values for hazard risk assessment, Nat. Hazards, 52, 453-479, 2010b.

Smith, D. I.: Flood Damage Estimation - A Review of Urban StageDamage Curves and Loss Functions, Water SA, 20, 231-238, 1994.

Smith, K. and Ward, R.: Floods: Physical processes and human impacts, John Wiley and Sons, Chichester, 1998.

SMWA: Standort Sachsen im vergleich mit anderen Regionen, Staatsministerium für Wirtschaft, Arbeit und Verkehr, Dresden, 2010.

te Linde, A., Aerts, J. C. J. H., Bakker, A., and Kwadijk, J.: Impact of water level reducing measures on flood peaks along the Rhine in a climate change scenario, J. Flood Risk Manage., 3, 248-269, 2010.

te Linde, A. H., Bubeck, P., Dekkers, J. E. C., De Moel, H., and Aerts, J. C. J. H.: Future flood risk estimates along the river Rhine, Nat. Hazards Earth Syst. Sci., 11, 459-473, doi:10.5194/nhess-11-459-2011, 2011.

Thieken, A. H., Müller, M., Kleist, L., Seifert, I., Borst, D., and Werner, U.: Regionalisation of asset values for risk analyses, Nat. Hazards Earth Syst. Sci., 6, 167-178, doi:10.5194/nhess-6-1672006, 2006.

Thieken, A., Kreibich, H., Müller, M., and Merz, B.: Coping with floods: preparedness, response and recovery of flood-affected residents in Germany in 2002, Hydrol. Sci. J., 52, 1016-1037, 2007.

Thieken, A. H., Olschewski, A., Kreibich, H., Kobsch, S., and Merz, B. Development and evaluation of FLEMOps - a new Flood Loss Estimation MOdel for the private sector, edited by: Proverbs, D., Brebbia, C. A., and Penning-Rowsell, E., Flood Recovery, Innovation and Response I, WIT Press, 315-324, 2008.
UNISDR: Global Assessment Report on Disaster Risk Reduction Revealing risk, redefining development, United Nations, Geneva, 2011.

van der Sande, C.: River flood damage assessment using IKONOS imagery, European Commission - Joint Research Centre, 2001.

Vanderkrimpen, P., Melger, E., and Peeters, P. L.: Flood modeling for risk evaluation - a MIKE FLOOD vs. SOBEK 1D2D benchmark study, in: Flood Risk Management: Research and Practice, edited by: Samuels, P., Huntington, S., Allsop, W., and Harrop, J., CRC Press, 2009.

Vanneuville, W., Maddens, R., Collard, C., Bogaert, P., de Maeyer, P., and Antrop, M.: Impact op mens en economie t.g.v. overstromingen bekeken in het licht van wijzigende hydraulische condities, omgevingsfactoren en klimatologische omstandigheden, Vakgroep Geografie, Universiteit Gent, Gent, Belgium, MIRA/2006/02, 2006.

Verburg, P. H., Ellis, E. C., and Letourneau, A.: A global assessment of market accessibility and market influence for global environmental change studies, Environ. Res. Lett., 6, 034019, doi:10.1088/1748-9326/6/3/034019, 2011.

Vorogushyn, S., Lindenschmidt, K.-E., Kreibich, H., Apel, H., and Merz, B.: Analysis of a detention basin impact on dike failure probabilities and flood risk for a channel-dike-floodplain system along the river Elbe, Germany, J. Hydrol., 436-437, 120-131, 2012.

Ward, P. J., De Moel, H., and Aerts, J. C. J. H.: How are flood risk estimates affected by the choice of return-periods?, Nat. Hazards Earth Syst. Sci., 11, 3181-3195, doi:10.5194/nhess-113181-2011, 2011.

Zhai, G., Fukuzono, T., and Ikeda, S.: Modeling flood damage: case of Tokai Flood 2000, J. Am. Water Resour. Assoc., 41, 77-92, 2005. 